\title{
Antimicrobial Proteins: From Old Proteins, New Tricks
}

\author{
Valerie J. Smith ${ }^{{ }^{*}}$ and Elisabeth A. Dyrynda ${ }^{2}$ \\ ${ }^{1}$ Scottish Oceans Institute, School of Biology, University of St Andrews, \\ St Andrews, Fife, KY16 8LB, Scotland, UK \\ ${ }^{2}$ Centre for Marine Biodiversity \& Biotechnology, School of Life Sciences, \\ Heriot Watt University, Edinburgh, EH14 4AS, Scotland UK
}

*Corresponding author (vjs1@st-andrews.ac.uk)

\begin{abstract}
This review describes the main types of antimicrobial peptides (AMPs) synthesised by crustaceans, primarily those identified in shrimp, crayfish, crab and lobster. It includes an overview of their range of microbicidal activities and the current landscape of our understanding of their gene expression patterns in different body tissues. It further summarises how their expression might change following various types of immune challenges. The review further considers proteins or protein fragments from crustaceans that have antimicrobial properties but are more usually associated with other biological functions, or are derived from such proteins. It discusses how these unconventional AMPs might be generated at, or delivered to, sites of infection and how they might contribute to crustacean host defence in vivo. It also highlights recent work that is starting to reveal the extent of multi-functionality displayed by some decapod AMPs, particularly their participation in other aspects of host protection. Examples of such activities include proteinase inhibition, phagocytosis, antiviral activity and haematopoiesis.
\end{abstract}

\section{Key words:}

Antibacterials, penaeidins, crustins, anti-lipopolysaccharide factors, lysozyme, histones, shrimp, crabs, crayfish, phagocytosis, ETosis, haematopoiesis

\section{Highlights}

- An analysis of recent research on crustacean AMPs

- An overview and critique of recent findings (within last 5 years) of AMP gene expression patterns

- Exciting new research presents an integrated scheme, which depicts the multifunctionality of AMPs within the crustacean cellular immune responses 


\section{Introduction}

Conventional antimicrobial peptides are small (usually $<10 \mathrm{kDa}$ or $<100$ amino acids) cationic and amphipathic proteins that kill a broad spectrum of micro-organisms in a stoichiometric manner. It has now been nearly 40 years since defensins, cecropins and magainins were independently isolated from mammals, insects and amphibians by Bob Lehrer, Hans Boman and Michael Zasloff, respectively. Since then thousands of antimicrobial peptides (AMPs) have been reported by other workers, with over 5,500 listed on protein, gene or AMP databases. Indeed at least 13 AMP-dedicated databases have been created since 2002, with, to the best of our knowledge at the time of writing, the most recent being LAMP (Zhao et al., 2013a). However, different databases have been compiled for different purposes and search criteria, so do not necessarily list every AMP discovered. What these databases do show is that AMPs are expressed in the blood, mucosa and other body tissues of a very wide range of taxa, from simple protists and acoelomate invertebrates to mammals, with some also identified in plants, yeasts or fungi (http://aps.unmc.edu/AP/main.php). Clearly, AMPs are no longer the new kids on the immunology block but are now fully recognised potent effectors against infection and, as such, are a key part of innate inflammatory and mucosal defences. We can therefore regard AMPs as established and evolutionarily very old defence proteins.

As review articles have already been published that describe the various AMP families in crustaceans and other invertebrate taxa (Smith et al., 2008; Smith et al., 2010; Sperstad et al., 2011; Tassanakajon et al., 2011, 2015; Song \& Li, 2014), the present article is concerned with considering recent advances in our knowledge of crustaceans AMPs (i.e. over the last 5 years) but places this within the context of established knowledge. It focuses primarily, but not exclusively, on decapods, as this group of crustaceans are a major focus of research on account of their economic importance in aquaculture. There is an ever growing problem of disease in shrimp aquaculture and the farming of other comestible decapod species, mainly through increased intensification in the farming methods and expansion of global markets for brood-stock and seed. This, of course, is the major driver for much of the funding that underpins research, so it is not surprising that antimicrobial peptides and the factors that regulate their transcription and synthesis are amongst the most frequently studied immune proteins in these decapods.

This article will, first, give an overview of the range of AMPs produced by crustaceans, followed by a survey of the current landscape in our understanding of their antimicrobial activities and patterns of expression. It will then discuss new research that reveals some quirky aspects of their biological roles and participation in host defence. 


\section{AMPs in crustaceans: A brief survey}

Following the purification of the first crustacean AMPs, the proline-rich peptide, Bac-C, isolated from the haemocytes of the shore crab, Carcinus maenas (Schnapp et al., 1996) and the penaeidins from the shrimp, Litopennaeus vannamei (Destoumieux et al., 1997), several families are now known to exist (Tables 1 and 2), with numerous individual, novel AMPs also recorded (Table 3). In terms of the number of peptides known, the families of crustins and penaeidins are the most prominent, so are commonly regarded as the two 'main' groups for the Crustacea.

\subsection{Crustins}

The largest family of crustacean AMPs is the crustin group, of which more than 50 such proteins are now reported in the literature or lodged on databases. The first crustin to be discovered was purified from C. maenas haemolymph (Relf et al., 1999) and was only later designated as 'carcinin' by Brockton et al. (2007). The term crustin was coined following the discovery of highly similar proteins in shrimp (Bartlett et al., 2002). Crustins have since been found to occur across many decapod taxa (Tables 1 and 2), with crustin-like sequences also detected in amphipods, branchiopods and copepods (see review by Smith et al., 2008). Remarkably, crustin-like sequences have even been found in ants (Zhang \& Zhu, 2012), showing that they are not necessarily confined to decapods, or even the crustacean group as whole. Crustins are constitutively expressed, cationic, cysteine-rich AMPs ( 7-14 kDa), containing a signal sequence and usually 1 , or occasionally 2 , whey acidic protein (WAP) domains (Smith et al., 2008; Li et al., 2012). WAP domains are characterised by a conserved arrangement of 8 cysteines that form a 4-disulphide core at the $\mathrm{C}$ terminus. The number of WAP domains, together with the presence or absence of other cys-rich or gly-rich domains, is the basis of crustin classification into four main types, namely I-IV (Table 1; Smith, 2011). Crustins act primarily against Gram-positive bacteria, although some have also been reported to kill Gram-negatives (Table 2; Li et al., 2012). In general, Gram-positive bacteria are killed at relatively high MIC values compared with some other invertebrate AMPs, while killing of Gram negatives is achieved at quite low MIC levels (Table 2). For example, a Type III crustin from the shrimp, Penaeus monodon, is active against Gram-negative bacteria with an MIC value of $<5 \mu \mathrm{M}$ (Amparyup et al., 2008a).

\subsection{Penaeidins}

The penaeidins are the second largest group of crustacean AMPs with some 40 types discovered from at least 8 shrimp species so far (reviewed by Tassanakajon et al., 2011; Song \& Li, 2014). Penaeidins were initially identified from the shrimp, Litopenaeus vannamei, (Destoumieux et al., 1997) but have since been found in several other shrimp 
species including: Fenneropenaeus chinensis, F. indicus, L. stylirostris, L. schmitti, L. setiferus, Marsupenaeus japonicus and P. monodon (Tassanakajon et al., 2011; Shanthi \& Vaseeharan, 2012). Unlike crustins, penaeidins have yet to be identified outside the penaeid group. The encoded proteins comprise a signal sequence, and two domains: a long (ca 21-28 amino acid) proline-arginine rich domain at the $\mathrm{N}$ terminus and a compact, cysteine-rich (typically six cysteine residues) domain at the $C$ terminus. Currently, penaeidins are the only crustacean AMP family to have had a universally agreed classification and nomenclature scheme based on amino-acid similarity (Gueguen et al., 2006). This was organized as a database called 'Penbase' and hosted at http://www.penbase.immunoaqua.com, although the site no longer appears to be active. Four classes of penaeidins are recognised (Tables $1 \& 2$ ), with their spectra of activities mainly against Gram-positive bacteria and fungi. More strongly antimicrobial than crustins in terms of their MIC (Table 2), penaeidins also possess chitin-binding activity, which is thought to account for their antifungal properties and confers antimicrobial protection to the shrimp carapace (Destoumieux et al., 2000).

\subsection{Anti-lipopolysaccharide factors}

Anti-lipopolysaccharide factors (ALFs) were originally purified from the amoebocytes of the chelicerate horseshoe crabs, Limulus polyphemus and Tachypleus tridentatus (Tanaka et al., 1982; Ohashi et al., 1984) and only discovered from signature sequences in EST libraries of shrimp L. vannamei and L. setiferus much later (Gross et al. 2001). Originally identified as binding proteins in horseshoe crabs, they are now known to also have antimicrobial activity and are, at present, routinely considered as AMPs (Tassanakajon et al., 2011). The ALF family comprises five groups, defined by their amino acid sequences, the characteristics of their lipopolysaccharide binding sites and their predicted pl values. Group A contains both anionic and cationic peptides whereas Groups B and C have only cationic ones, but differ in the number of introns in the genes encoding them, as well as their tissue distribution. Group D differs from the other groups in as much as it contains only strongly anionic peptides. The fifth, Group E, is another cationic group recently identified from the transcriptome of the haemocytes and hepatopancreas from the kuruma shrimp, Marsupenaeus japonicus, and confirmed as separate to Groups A-D by sequence alignments and phylogenetic analyses (Jiang et al., 2015). While ALFs in general have potent, broad-spectrum antimicrobial activities (Table 2), there are some differences between these groups. For example, Groups A, B, C, E have strong antibacterial and binding properties (Jiang et al., 2015) whereas Group D has only weak killing and binding properties. The biological role(s) played by Group D ALFs has yet to be elucidated (Rosa et al., 2013). 


\subsection{Lysozymes}

Although not fitting the traditional definition of an AMP, lysozyme is widely considered to be an antimicrobial protein. It is a muramidase that primarily exerts its effects on target bacteria by cleaving the $\beta 1,4$-glycosidic bonds in the peptidoglycan of bacterial cell walls. Lysozyme activities have been observed and quantified in the immune cells of many animal species, although its investigation in crustaceans has been relatively limited compared with other taxa. As with crustins, penaeidins and ALFs, knowledge of lysozyme in crustaceans has come largely from cDNA or EST data coupled with recombinant protein assays (e.g. Pan et al., 2010; Supungul et al., 2010).

Of three main types of lysozyme recognised across animal taxa: namely the c- (chicken), g(goose) and i- (invertebrate) types (reviewed by Callewaert \& Michiels, 2010), only c- and itypes have been found in crustaceans (Supungul et al., 2010; Kaizu et al., 2011; PeregrinoUriarte et al., 2011). These types are notable for also killing some Gram-negative bacteria (Mai \& Hu, 2009; Supungal et al., 2010), with the activity, at least in c-types, attributed to the presence of a hydrophobic region in the molecule (Touch et al., 2004) that enables them to kill in a non-enzymatic way (Callewaert \& Michiels, 2010).

\subsection{Other AMP types}

It is clear from Tables 2 and 3 that, while sequence-driven discovery of AMPs is highly successful in discovering new peptides or isoforms, whether from existing families or as completely new AMP molecules, greater novelty comes from the bioassay guided purification of AMPs from cells or tissues (Table 3). Good examples include arasin-1 and hyastatin, isolated from haemocytes of the spider crab, Hyas araneus, (Stensvåg et al., 2008; Sperstad et al., 2009), These are unusual AMPs as they have a 'chimeric'-type structure, i.e. one composed of several distinct regions, such as pro-arg, gly-rich or cys-rich (Stensvåg et al., 2008; Sperstad et al., 2009). Arasin-1 is a cationic, broad-spectrum protein, which has some sequence similarity to bovine bactenecin-7 and porcine PR-39, the insect metalnikowin as well as the Bac-like AMP of C. maenas and astacidin-2 (Stensvåg et al., 2008). A later study demonstrated chitin-binding activity of arasin fragments, and also showed that the likely mode of killing was not lytic, but more probably mediated in the intracellular environment akin to the mode displayed by PR-39 (Paulsen et al., 2013). Bacterial inhibition assays made on different synthetic fragments of arasin-1 have revealed that the antimicrobial activity is reliant on the cys-rich region at the $\mathrm{C}$ terminus with the $\mathrm{N}$ terminus showing weaker antimicrobial effects but strong chin-binding properties (Sperstad et al., 2009). Hyastatin is similarly a cationic peptide that shows broad-spectrum antimicrobial activity, but consists of three distinctly different domains, namely a gly-rich 
region at the $\mathrm{N}$-terminus, a short pro/arg-rich region, and a cys-rich region resembling that of penaeidins (Sperstad et al., 2009). Subsequently, a hyastatin-like sequence has been found from a haemocyte cDNA library of the crab, Portunus trituberculatus (Shen et al., 2010). Whether the corresponding protein has similar killing or binding properties to hyastatin from $H$. araneus has yet to be established.

Amongst other haemocyte-derived AMPs recently identified from the haemocytes of crustaceans, is callinectin, a pro-arg-rich cationic protein, expressed by the blue crab, Callinectes sapidus (Noga et al., 2011) (Table 3). However, despite showing some homology to arasin-1 from $H$. araneus, callinectin differs in its sequence in a number of respects, most notably in modifications of its tryptophan residue, so is therefore considered as a distinct type of crustacean AMP (Noga et al., 2011). It would be interesting to know if other members of the Brachyura show arasin- or callinectin-like antimicrobial proteins or genes.

An important group of cationic AMPs are defensins, which are widespread throughout animal taxa, including arthropods (reviewed by Tassanakajon et al., 2015), although their presence has yet to be confirmed from crustaceans. Two accounts have recently been published recording defensin-like isoforms from haemocyte cDNA libraries of the Japanese spiny lobster, Panulirus japonicus, and the Caribbean spiny lobster, $P$. argus (Pisuttharachai et al., 2009; Montero-Alejo et al., 2012) (Table 3). Sequence data and phylogenetic analyses of these confirm they have high levels of identity with vertebrate $\beta$ defensins, but currently no information is available about their structure or antimicrobial activities (Pisuttharachai et al., 2009; Montero-Alejo et al., 2012). The possible existence of defensins or defensin-like peptides in crustaceans is therefore an interesting area for further research.

In contrast to cationic AMPs in crustaceans, relatively few anionic AMPs are known in decapods, with only two reported to date (Table 3). One is scygonadin, a $10.8 \mathrm{kDa}$ protein, purified from the seminal fluid of male mud crabs, Scylla paramamosain (formerly $S$. serrata) (Huang et al., 2006). The structure of scygonadin is yet to be determined, but its amino-acid sequence structure shows no significant homology to any crustacean AMPs described to date (Huang et al., 2006). It has activity against Micrococcus luteus and, to a lesser extent, Aeromomas hydrophila (Huang et al., 2006). A protein with ca. $94 \%$ sequence similarity to scygonadin, was later purified from haemocytes of S. paramamosain by Yedery \& Reddy (2009). Recent research has revealed that transcripts of the gene encoding the protein occur in ovary, spermatheca, haemocytes and gill of females, and in 
males, it is evident in the ejaculatory duct, haemocytes and mid gut (Xu et al., 2011). Interestingly, expression levels vary in both species pre and post mating, with high levels in the male ejaculatory duct significantly falling post mating, while in females, expression in the spermatheca rises substantially from relatively low levels after mating (Xu et al., 2011). These results indicate that scygonadin might be important for protection of sperm during copulation, or has some other purpose, as yet unknown. The second anionic AMP known to date in crustacean is stylicin, which was identified as a transcript from haemocytes of Litopenaeus stylirosis (Rolland et al., 2010) (Table 3). The recombinant protein is $8.9 \mathrm{kDa}$ and has 13 cysteine residues at the $C$ terminus (Rolland et al., 2010). However, these do not form a WAP domain and there is no significant homology with other listed AMPs (Rolland et al., 2010). Stylicin has strong activity against the crustacean fungal pathogen, Fusarium oxysporum, with weaker activity against three species of Vibrio (Rolland et al., 2010) (Table 3).

Unfortunately, there are very few AMPs reported for non-decapod crustaceans, with currently only two accounts published. The first is armadillidin, purified from the haemocytes of the terrestrial isopod, Armadillidium vulgare (Herbinière et al., 2005) (Table 3). This AMP is a small $(5.2 \mathrm{kDa})$ gly-rich peptide that shows activity against Gram-positive bacteria (Herbinière et al., 2005). Neither amino-acid nor DNA sequences of the peptide have significant similarity with other arthropod gly-rich AMPs (Herbinière et al., 2005), so it is regarded as a novel peptide and not a member of any existing families. The second nondecapod AMP was purified from whole body homogenates of krill, Euphausia superba on the basis of its activity against the Gram-positive bacterium, Staphylococccus aureus (Zhao et al., 2013b). It was designated as CMCC-1 and shown, by scanning electron microscopy, to cause damage to the bacterial cell walls and membranes (Zhao et al., 2013b). The ability of CMCC-1 to similarly affect Gram-negative bacteria has not been tested as yet, nor are there any further details available about its structure. Therefore it remains unclear whether it is a novel peptide or belongs to an existing peptide classification.

\section{Antimicrobial activities of non-immune proteins}

In addition to proteins that are considered dedicated AMPs, there are also a number of molecules that have strong antimicrobial effects but are better known for other biological functions, or else are generated as a cleavage product from a 'parent' protein with a nonimmunological role. A good illustration is the histone group. These proteins are chiefly responsible for maintaining nuclear organisation, especially the packaging of chromosomes within the nucleus. As long ago as 1958, Hirsch reported that histones from humans have potent antibacterial effects, although it was not for another 40 or so years before this 
important discovery was appreciated within the wider context of host defence. Their recognition as contributors to host protection against infection was stimulated to some extent by the finding that several histones or histone fragments are active against bacteria in the skin exudates of fish (Kim et al., 1996; Park et al., 2000; Fernandes et al., 2002; see also review by Smith \& Fernandes, 2008) and amphibians (Kawasaki et al., 2003). As histones are highly conserved, histones or histone-derived fragments from crustaceans would be expected to display similar microbicidal properties, and indeed histone $\mathrm{H} 2 \mathrm{~A}$ from L. vannamei has been shown to do so (Patat et al., 2004). This H2A completely inhibits the growth of Micrococcus luteus at a concentration of $4.5 \mu \mathrm{M}$, with a mixture of $\mathrm{H} 2 \mathrm{~B}$ and $\mathrm{H} 4$ achieving the same level of killing at $3 \mu \mathrm{M}$ (Patat et al., 2004). A study of recombinant $\mathrm{H} 2 \mathrm{~A}$ from the freshwater prawn, Macrobrachium rosenbergii, has now confirmed that this histone has antibacterial effects against both Gram-negative and Gram-positive bacteria (Arockiaraj et al., 2013a). Molecular analysis of its cDNA has demonstrated that it has a predicted molecular mass of $15 \mathrm{kDa}$ with a very high sequence identity (99\%) to other known histone H2As, including that from Penaeus monodon (Arockiaraj et al., 2013a). Based on structural analyses, these authors go on to suggest that the active domain is at the $\mathrm{N}$ terminus (Arockiaraj et al., 2013a). Interestingly, expression of the gene encoding $\mathrm{H} 2 \mathrm{~A}$ in $M$. rosenbergii, is up-regulated sevenfold $12 \mathrm{~h}$ after experimental infection with bacteria (Aeromomas hydrophilia or Vibrio harveyi) or viral agents (White Spot Syndrome Virus) (Arockiaraj et al., 2013a). A parallel study also on M. rosenbergii, by the same group, has further demonstrated that the $\mathrm{N}$ - and $\mathrm{C}$-termini of histone $\mathrm{H} 4$ have microbicidal activities towards Gram-positive and Gram-negative bacteria, with, again, up-regulation of gene expression, most notably in the gills, after injection of $V$. hydrophilia, $V$. harveyi or WSSV (Chaurasia et al., 2015). Clearly, histones are potentially powerful antimicrobial defence molecules but it is not easy to understand how they contribute to host defence in vivo, as they are tightly enclosed with the cell nucleus. This raises the questions: how and under what circumstances would they be liberated to the extra-nuclear environment to interact with potential pathogens or is the antimicrobial activity determined for these proteins in vitro biologically irrelevant in vivo?

Another group of non-immune proteins in crustaceans that have strong microbicidal effects are peptides generated from haemocyanin, a copper-binding protein synthesized mainly in the hepatopancreas and haemocytes (Rainer \& Brouwer, 1993; Huang et al., 2014) that is more normally regarded as a respiratory protein in crustaceans. The peptide fragments were first isolated from the C-terminus of haemocyanin of $L$. vannamei by DestoumieuxGarzón et al. (2001). These shrimp peptides have a net negative charge and molecular masses of ca $2.75,7.98$ or $8.34 \mathrm{kDa}$ respectively, quite unlike penaeidins or crustins. They 
appear to be active only against fungi, probably through binding to chitin (DestoumieuxGarzón et al., 2001). Another AMP derived from haemocyanin, named astacidin-1, has been purified from the plasma of the crayfish, Pacifastacus leniusculus (Lee et al., 2003), with, more recently, a further type of astacidin identified from another crayfish, Procambarus clarkii (Shi et al., 2014). This new astacidin not only inhibits the growth of fungi, but also binds bacterial cell wall components (such as peptidoglycan, lipopolysaccharide and lipoteichoic acid) (Shi et al., 2014). It appears to exert its effects on fungi by damaging the membrane by pore formation (Choi \& Lee, 2014). RNAi knock down experiments show that, in addition to microbial killing, this new astacidin participates in bacterial clearance in vivo, as the rate at which injected bacteria are removed from the circulation is impaired in the knock-down animals (Shi et al., 2014). Antibacterial and antifungal activities have similarly been reported for two recombinant $\mathrm{C}$-terminus fragments derived from haemocyanin cDNA extracted from $F$. chinensis and tested against a panel of Gram-negative and Gram-positive bacteria or fungi (Qiu et al., 2014). As yet, it has still to be clarified how these fragments are cleaved from haemocyanin in vivo. It could be via proteases liberated from haemocytes, as suggested originally by Destoumieux-Garzón et al. (2001), but it could occur non-proteolytically as a recent paper has found that in the porcelain crab, Petrolisthes cinctipes, haemocyanin fragmentation occurs after non-lethal heat-shock (Garland et al., 2015). Interestingly, heat-shock enhances haemocyanin mRNA expression in L. vannamei (Loc et al., 2013) possibly to replenish the haemocyanin pool depleted by fragmentation. This is an intriguing finding because non-lethal heat shocking has been documented to improve resistance of shrimp against bacterial and viral infections (de la Vega et al., 2006; Sung et al., 2007), contrary to the widely held expectation that stress impairs immune function in most animals. Indeed, the use of heat shock has been argued by some authors (reviewed by Sung \& MacRae, 2011) to be a useful non-traumatic method for enhancing humoral and cellular innate immunity in aquaculture species.

Contrary to this belief, the study on L. vannamei by Loc et al., (2013) further showed that heat shock confers no overall improvement in survival of post-larvae after challenge with Vibrio harveyi, with expression of crustin and peroxinectin found to remain unchanged and mRNA levels of penaeidin actually reduced. Heat shocking therefore remains an unproven and controversial immune-stimulating strategy.

Of course, histones and haemocyanin occur in all crustacean species but there are also species-specific molecules in decapods that appear to have antibiotic effects whilst not conforming to the template of 'classical' AMPs. One such group is the lectins. These carbohydrate-binding glycoproteins comprise a diverse array of molecules that occur widely across many animal taxa now categorized into as many as 13 families (see the Animal 
Lectin Database: http://www.imperial.ac.uk/research/animallectins/). Initially investigated within an immunological context as agglutinins of red blood cells or bacteria, they were originally thought to be important as opsonins, especially in molluscs and ascidians. They are now known to play extremely diverse roles in host defence in invertebrates, being involved in cell adhesion and binding, recognition and, in some cases, also direct antimicrobial activity. Whilst their presence in decapods has been noted for some time (see for example, Sun et al., 2007; 2008), they have only more recently come to prominence through advances in nucleic acid technologies that has allowed sequence identification from resources such as cDNA or EST libraries. Data mining of the shrimp transcriptome, alone, has revealed sequences that match seven types amongst the 13 families of lectins (reviewed by Wang \& Wang, 2013). That they may contribute to antimicrobial defence is demonstrated by the finding that a recombinant lectin from $F$. chinensis inhibits the growth of several micro-organisms, including bacteria and fungi, with activity against Gram-positive bacteria stronger than that against Gram-negatives (Sun et al., 2008). The lectin responsible is a calcium-dependent C-type, defined as such by its possession of a single Ctype lectin domain comprising four conserved cysteine residues that make up two disulphide bridges which stabilize the molecule (see review by Wang and Wang, 2013). The gene is highly expressed in the hepatopancreas of $F$. chinensis with lower levels expressed in the stomach and intestine (Sun et al., 2008) indicating it might help protect against infection, especially via the gut. It is noteworthy that the encoded protein is detectable in the plasma of infected or disease resistant shrimp and facilitates the clearance of $L$. anguillarum from the circulation (Wang et al., 2009a,b).

\section{The current landscape in gene expression}

By far the greatest intensity of research effort into crustacean AMPs in recent years has been into their patterns of expression in different body organs or tissues and after various experimental treatments of the host, particularly in vivo challenge with micro-organisms or compounds thought to stimulate immunity. Several decapod species have been the subject of such analyses, although work has tended to be directed at shrimp, no doubt because of their huge importance in aquaculture. A diversity of challenge microbes, or structural components from them has been used as non-self agents, with bacteria and virus being especially popular. Tables 4 to 6 provide a representation of some of the results obtained since 2010. The examples given in these tables are not exhaustive, but are intended to be representative of how individual AMPs respond to different immune challenges. For simplicity, changes in expression are indicated as either up regulation (upward pointing arrows) or down regulation (downward pointing arrows) or no significant change (NS). 
Whilst each table is devoted to a particular family of AMP, there are some interesting trends that emerge by comparison across the tables.

\subsection{Bacterial challenge}

Given that the main AMP families in crustaceans were discovered by bioassay-guided isolation, based on their ability to bind or inhibit the growth of bacteria, it is not surprising that bacteria have been most frequently used as the challenge agents. Results have been obtained from numerous bacterial species, including Gram-negative and Gram-positive strains, both pathogenic and non-pathogenic for decapods. For reasons of space, only the Gram staining characteristic of the bacteria rather than individual species names are used in the tables.

In general, gene expression of the main AMP families tends to be up-regulated following bacterial challenge, and this is apparent across the different shrimp and crab species used. Frequently, up-regulation is observed in response to both Gram-negative and Grampositive bacterial challenge, but, since the native or recombinant AMPs can be more active in vitro against one Gram-reactive type rather than the other, it might be expected that this would also be reflected in their gene expression. However, this does not appear to be the case. Most of the significant changes in gene expression are reported from the haemocytes as these cells are usually the source of isolation for the AMPs. Where significant changes have been noted in other tissues, these are commonly the gills, hepatopancreas or haematopoietic tissues. As these organs are highly vascularised, up-regulation is probably due to a major contribution from the haemocytes. It would be useful in gene expression studies to make more use of in situ techniques to confirm whether changes in vascularised tissues are originating from haemocytes or other cell types.

When considering individual families, the gene expression of crustins in particular might be expected to show more up-regulation with Gram-positive species. Instead, the trend is predominantly either up-regulation or no change in response to both Gram-reactive types. One example where no changes have been observed is a report by Sperstad et al. (2010). These authors performed one of very few in vitro experiments where each of the 3 main cell types (namely hyaline, semi-granular and granular) were cultured separately with bacteria. It is therefore a valuable study that clarifies the level of transcription in different haemocyte types. It is possible that Sperstad et al. (2010) failed to detect significant changes is because cells synthesising crustins need interactions with other immune factors to drive production of the peptides. A recent study using haemocytes from $L$. vannamei has 
confirmed that crustin gene expression is significantly higher in semi-granular and granular haemocytes (Yang et al., 2015).

A second example where no change has been recorded with bacterial challenge is that of Soonthornchei et al. (2010), who investigated crustin expression in the gut of $P$. monodon (Table 4). These workers used an in vivo approach and examined tissue sections in addition to quantifying gene expression. An important observation made in this paper is that large parts of the gut tissue are severely damaged, together with mass infiltration of necrotic haemocytes after bacterial injection (Soonthornchei et al., 2010) (Table 4). Again, given that the haemocytes are predominantly responsible for AMP transcription, this would have influenced the results of the gene expression.

Considering the response to bacterial challenge in penaeidins and ALFs, the patterns are more consistent than those reported for crustins (Table 4-6). Although fewer publications since 2010 have assessed penaeidin expression following bacterial challenge, the results of these analyses still show consistent up-regulation of this AMP gene. The exception to this is, once more, the in vivo work by Soonthornchei et al., (2010), who had measured penaeidin expression in tandem with the crustin (Tables $4 \& 5$ ). The lack of significant change in the penaeidin expression would be influenced by the high numbers of dead haemocytes in the vicinity of the gut, similar to the situation with crustins. The consistent pattern of up-regulation of the ALF genes noted in Table 6 could be influenced by their binding capabilities as well as by their antimicrobial effects. When bacteria are present, ALF proteins will naturally bind to them, thus likely stimulating production of new protein.

A degree of caution is necessary in interpreting these trends for a number of reasons. For example, recognition of Gram-positive and Gram-negative bacteria involves different pathways depending on the pathogen-associated molecular patterns that are unique to that type of micro-organism. Furthermore, bacterial species differ widely in the configuration of their wall or membrane structure, with some showing atypical Gram reactions. Mycoplasmas are especially interesting as these lack cell walls entirely and members of this group, such as mollicutes, are widespread arthropod pathogens. An example of the response to mollicute exposure is the study by Meng et al. (2014) (Table 4). These authors used the pathogen, Spiroplasma eriocheris, to challenge the crab, E. sinensis. In contrast to the general trends observed with bacterial challenge, crustin expression was significantly down-regulated (Meng et al., 2014). This study also brings home the message that the host response to pathogens will differ to that towards non-pathogens, as the former often have characteristics that either render them wholly or partially insusceptible to the host immune 
system, or out-pace the host reactions. Non-pathogens, by contrast, would likely trigger a strong defence response and be contained. The wide array of bacterial strains used as challenge models makes it difficult to know how well these expectations are upheld.

\subsection{Viral challenge}

Viral challenge is routinely performed using White Spot Syndrome virus (WSSV) or its envelope or tail proteins, such as VP28, probably reflecting the huge problem that WSSV presents to crustacean aquaculture. Although many experiments have quantified AMP gene expression in response to WSSV, the general lack of anti-viral activity in these peptides means that gene expression results may be arising from other aspects of WSSV infection in the body. Virally infected shrimp become quickly become moribund and opportunistic bacterial infections are likely to be occurring in tandem and unobserved.

There are no clear trends in response to WSSV challenge in either crustin or penaeidin expression across the various species (Tables $4 \& 5$ ). Where changes have been documented, it is the haemocytes that are most likely to show expression changes, sometimes even, both up and down during the course of one experimental study (indicated by both up and down arrows on the same row in Tables $4 \& 5$ ). Where such a pattern is observed, this may often arise from changes in expression between the early and late phases of the host response (Tables $4 \& 5$ ). It is common for the duration of experiments to be between 24 and $96 \mathrm{~h}$, with sampling times within those ranging from $0.5 \mathrm{~h}$ post-injection to 72 and $96 \mathrm{~h}$ stages (Tables $4 \& 5$ ). Variability in crustin and penaeidin expression often comes from an early (3-12 h) down regulation, followed by a short period of no change, before an up-regulation at $48 \mathrm{~h}$ or later (Table $4 \& 5$ ). As it is well established that the immediate host response to immune challenge is for the haemocyte number to fall dramatically (Smith et al. 2003; 2010), it would be interesting to follow the total and differential haemocyte count in parallel with the gene expression, as this could indicate whether gene expression was linked with the proportions of viable cells responsible for producing the transcripts. It would also be useful to run challenge experiments over much longer durations, as this might indicate whether regular cellular renewal patterns coincided with changes in gene expression.

Under viral challenge conditions, the pattern of ALF expression is much more consistent than those observed in the other two main AMP families (Table 6). As happens with injection of bacteria, ALF expression appears to be consistently up-regulated on exposure to WSSV (Table 6). This again may or may not be due to other consequences of viral infection, e.g. ALF responding to secondary infections by bacteria. Where a dual up- and 
down-regulation of ALF is recorded, this again most frequently relates to time differences (e.g. Liu et al., 2013) or different expression patterns in ALF isoforms (e.g. Ren et al., 2012).

\subsection{Fungal challenge}

The number of gene expression studies using fungal agents is notably fewer than those using bacteria or viruses. The general trend is up-regulation of crustins and ALFs in the haemocytes. However, with few studies to draw on, this could not be regarded as a clear pattern representative of typical responses to fungi. There is also a question over the relevance of what organism is used to represent a fungal challenge - terrestrial yeast species are commonly used in experiments with crustaceans, but are not necessarily the most appropriate. In the natural environment, fresh and brackish-water shrimp species in particular, are most likely to encounter eukaryotic pathogens from groups such as the water molds (oomycetes) (Philips et al., 2007). These organisms are widespread in aquatic environments and many reports exist of their pathogenicity to fish and shellfish (Philips et al., 2007). However, with the exception of extensive studies of the response of crayfish to the oomycete pathogen, Aphanomyces astaci, there has been almost complete neglect of the response to these pathogens in other species.

\subsection{Immunostimulation}

Immunostimulation is a major area of research in crustacean immunology, arising from the massive disease problems that affect the aquaculture industry and the lack of effective treatments to combat them. In general, immunostimulants are regarded as substances administered to farmed fish and shellfish with intent to enhance innate immune reactivity and thus improve resistance or survival following infection by potentially harmful microorganisms. The route of administration is usually dietary, thus the term 'probiotic' (i.e. a microbial component that confers a general health benefit to the host) is often used interchangeably with 'immunostimulant'. For the purposes of this review, 'immunostimulant' is regarded as any substance given to crustaceans with the specific intent of boosting immunity and/or survival following an experimental challenge. Both commercial and candidate (i.e. those under testing) immunostimulants arise from extremely numerous and diverse bacterial and plant sources, creating problems of consistency, quality and contamination when used in experimental trials (reviewed by Smith et al., 2003; Hauton et al., 2015), thus further complicating interpretation of results. For reasons of space, it is not possible to give in the present paper details of all individual immunostimulants used in recent studies. 
Comparing crustins, penaeidins and ALF gene expression in response to immunostimulants, the general trends show a clear split between the different families (Tables 4-6). The penaedins and ALFs tend to show up-regulation when immunostimulants are administered (Tables $4 \& 5$ ). However, the up-regulation in penaedins is more frequently seen in the haematopoietic tissue, in contrast to microbial challenge experiments where most significant changes were reported from the haemocytes (Table 5). The number of studies concerning ALF expression in immunostimlated animals is fewer, with representative examples showing up-regulation (Table 6).

The expression of the crustins shows no clear trends, with studies recording both up- and down-regulation in several species (Table 4). In contrast to bacterial or viral agents, most of the significant changes occur in the tissues rather than from the circulating haemocytes (Table 4). However, two species (L. vannamei and M. japonicus) show crustin up-regulation in the gut with concurrent down-regulation in the hepatopancreas following immunostimulation. Some crustin up-regulation is also observed in the haematopoietic tissue of $M$. japonicus, as well as the haemocytes, gills and hepatopancreas of $P$. monodon (Table 4). As considered above, it is important to consider the number and proportion of different haemocyte types in circulation and in the tissues. A further consideration is that reports exist of some immunostimulants having cytotoxic effects on haemocytes (Hauton et al., 2004), which would impact on gene expression.

Given the lack of detail provided on some immunostimulant preparations, together with the issues already mentioned about quality and consistence of the various compounds, it is becoming clear that it is essential to set in place a standardized framework to understand how best to develop effective preventatives and cures in crustacean aquaculture. Hauton et al. (2015) have proposed a set of guidelines regarding the 'Minimum Information required to Support a Stimulant Assessment Experiment' (MISA) which would greatly benefit the research area. These guidelines suggest inclusion of all details of the host animals, e.g. age, life-history, origin, as well as full biochemical characterization of the test substance, recording of mortalities, and molecular characterization of the species/strain of test pathogen (Hauton et al., 2015). Implementing such elements into immunostimulant research would greatly improve the quality and reproducibility of results and make possible much more meaningful comparisons across numerous publications.

\section{Functionality of crustacean AMPs}

Despite their power to reveal changes within the host to life experiences, expression studies do not help us discover new or unusual types which may exist and contribute to 
host defence. In particular, as most gene studies have tended to concentrate on the dominant families of AMPs, mainly crustins, penaeidins, ALFs and lysozymes, far less is known about expression patterns of the less prominent AMP types. Sadly, too, there have been far fewer studies of the native proteins of all AMP types and their isoforms compared to recombinant ones, with most functional analyses concerned with measurements of antibacterial activities against different microbial strains. This leaves a dearth of information on several other aspects of their functionality in vivo. For example, the regulation of AMP transcription and the processes by which the mature proteins are delivered from their sites of synthesis to wounds or loci of infection has been poorly investigated, as has the wider ability of AMPs in crustaceans to contribute to immunity or to other physiological processes. However recent work is starting to shed light on the issues.

\subsection{Delivering the goods}

For most AMPs secreted at epithelial or mucosal surfaces, delivery would occur directly to the surface by exocytosis to protect against invasion through any breaches of the integument. For AMPs synthesised and contained within the granules of haemocytes, mature proteins would be released in a regulated way at times of need, with synthesis of new proteins induced by pattern recognition receptors, such as Toll or IMD. Certainly in recent years a growing number of sequence reports of Toll receptors from various decapod species have been published, showing that these genes are expressed across a wide range of tissues and are up-regulated after immune challenge (Arts et al., 2007; Yang et al., 2007, 2008; Mekata et al., 2008; Vidya et al., 2014). A very recent study on crayfish has shown that Toll regulates expression of crustin, ALF and lysozyme in P. clarkii, and penaeidins in shrimp with attacin, Metchnikowin, and drosomycin over-expressed in Drosophila S2 cells (Wang et al., 2015). In addition, homologues of key elements of the immune deficiency (IMD) pathway that mediates immunity against Gram-negative bacteria in Drosophila spp, have been identified in F. chinensis and P. clarkii. (Lan et al., 2013). Other workers have identified homologs of the Rel/NF-kB transcription factors, for example: Relish (Huang et al., 2009), Dorsal (Huang et al., 2010), Spätzle-like proteins (Shi et al., 2009; Wang et al., 2012), and the adapter protein MyD88 (Qin et al., 2015). Also recently, Zhang et al. (2015b) have reported a further component, Flightless, from L. vannamei as a possible negative regulator in Toll signaling. A different negative regulator of the Tollmediated NF-kB pathway known in mammals that has recently been identified also in shrimp is SARM (sterile-alpha and armadillo motif-containing protein) (Wang et al., 2013). In mammals, SARM plays an important role in negatively regulating the TLR-mediated NFkB pathway (Carty et al., 2006). In L. vannamei silencing of SARM by dsRNA-mediated RNA interference increases expression of penaedins and ALF and reduces survival of 
shrimp to Vibrio infection (Wang et al., 2013). It therefore appears to also be a negative regulator of AMPs in shrimp and is thought to act by inhibiting the promoter activities of the AMPs (Wang et al., 2013).

Following recognition, transcription and synthesis mediated through Toll or IMD, the process of AMP delivery in phagocytic cells, would likely be by release into the phagosome, as found for penaeidins by Destoumieux et al. (2000). Killing would then be executed in conjunction with reactive oxygen species generated by the respiratory burst. However, not all crustacean haemocytes that express AMPs are phagocytic and in some species, notably members of the Brachyura, the phagocytic cells may contain few, if any, AMP-rich granules (Sperstad et al., 2010). For these haemocytes, it is generally assumed that AMPs are discharged from the granules directly into the haemolymph where they interact in the extracellular environment with any infective micro-organisms in their vicinity. Binding and killing by AMPs to bacteria outside the cell is probably most effective within the body organs or tissues as these are relatively confined spaces. However, in the open circulation, it may be less so, especially if the AMP has a short half-life, degrades or is diluted in the haemolymph beyond its minimal inhibitory concentration (MIC). Carcinin, for example, is predicted to have a relatively short half-life as it rapidly breaks down after cleavage from the leader sequence when it forms the active molecule, at least in vitro (Brockton et al., 2007). It is not known how long the protein is stable in vivo. A short half-life may be a safeguard against any possible deleterious effects of the mature protein on self-tissues, but the paucity of information about the stability and half-life of crustins in general means it is unclear if this is true for crustins in general. Carcinin, and other crustins also tend to have relatively high MIC values, at least compared to penaeidins or histones. Of the few studies made on native or recombinant proteins, MIC values of around 5-50 $\mu \mathrm{M}$ have been reported for crustins (Zhang et al., 2007; Liu et al., 2015), whereas penaeidins have MIC values in the range of 0.6-20 $\mu \mathrm{M}$ (Destoumieux et al., 1999; Hu et al., 2006), and MICs of ca 0.5-5.0 $\mu \mathrm{M}$ determined for histone H2A from shrimp (Patat et al., 2004) (Table 2). So, are there mechanisms by which AMPs can be delivered intimately to microbes dispersed throughout the haemolymph of crustaceans to effect killing, given that most species have a large open haemocoel and do these proteins contribute to physiology and homeostasis in ways other than microbial killing?

\subsection{Role in microbial trapping and encapsulation}

Encapsulation is a well recognized mechanism by which infective agents in the haemolymph can be sequestered from the general circulation and ultimately killed in vivo in crustaceans (reviewed in Smith et al., 2010) and other arthropods (Smith, 2010) but recent 
work on crab has demonstrated that there is an additional mechanism that helps to entrap micro-organisms in the blood and bring them into close contact with antimicrobial proteins released into the haemolymph from the haemocytes. This process, known as ETosis, was first discovered in human neutrophils (Brinkmann et al., 2004) but has since been reported for other mammalian leucocytes involved in inflammation (von Kockritz-Blickwede, 2008; Yousefi et al., 2008; Webster et al, 2010; Aulik et al., 2012). In every species studied, it entails the controlled release of de-condensed chromatin from the nucleus to the extracellular environment where the released nuclear material forms a cloud-like mesh (Brinkmann et al., 2004). Micro-organisms become ensnared on the mesh, thus preventing their spread around the body (Brinkmann et al., 2004). Importantly, antibacterial proteins, particularly hyper-citrullinated histones, discharged from the dying cell bind to and decorate the expelled chromatin fibres, so are brought into close contact with the ensnared microbes (Brinkmann et al., 2004; Fuchs et al., 2007). The response in neutrophils is associated with NADPH oxidase activation and downstream generation of reactive oxygen species (ROS), such as hydroxyl radicals, $\mathrm{H}_{2} \mathrm{O}_{2}$, singlet oxygen and $\mathrm{HOCl}$ (Fuchs et al., 2007; Stoiber et al., 2015). ROS work in combination with AMPs studded on the net structure to kill bacteria or other infective agents immobilized on the chromatin matrix (Fuchs et al., 2007). An equivalent process has subsequently been reported for chicken heterophils (Chuammitri et al., 2009) and fish phagocytes (Palic et al., 2007; Brodgen et al., 2014). The process is not confined to vertebrates, as similar entrapment of bacteria on externalized chromatin has been demonstrated with haemocytes from crab, C. maenas (Robb et al., 2014) (Fig 1) and shrimp, Litopennaeus vannamei. ( $\mathrm{Ng}$ et al., 2015) in vitro, with the bacteria Listonella anguillarum and E. coli, respectively, ensnared on the extruded DNA. The study on shrimp did not define which haemocyte type(s) display the response, but with $C$. maenas, the use of separated haemocyte populations in vitro has revealed that only the agranular hyaline haemocytes and the semi-granular haemocytes show the response (Robb et al., 2014). Neither the granular haemocytes nor the prohaemocytes of this animal display ETotic activity (Robb et al., 2014). Crucially, in vitro immunocytochemical studies have confirmed that externalised chromatin becomes decorated with histone H2A (Robb et al., 2014; Ng et al., 2015) with, in shrimp, the trapped E. coli permeabilised and killed on the chromatin fibres ( $\mathrm{Ng}$ et al., 2015). Pretreatment of the chromatin nets with DNAse dismantles net structure (Robb et al., 2014) and, if added before bacterial challenge, digestion of the chromatin traps reduces the number of the bacteria caught and killed ( $\mathrm{Ng}$ et al., 2015). As yet, the co-localisation of penaeidin or other conventional AMPs on the chromatin meshes structures not been demonstrated for either shrimp or crab, although ROS and hypercitrullinated histones would almost certainly contribute to killing on the nets. It is significant that ETosis is a process that enables histones to become exposed to infective agents within 
the haemocoel.

Perhaps more importantly, Robb et al. (2014) further showed that ETosis occurs in vivo in crab in response to injection of LPS, with the extruded chromatin also serving to ensnare circulating haemocytes. However, surprisingly, the protein, presumably peroxinectin, that binds to anti-MPO antibody does not co-localize with the extruded DNA, but instead tends to be present between intact, but flattened, haemocytes that surround the chromatin-rich core of the formed capsules (Robb et al., 2014), no doubt aiding the adhesion of haemocytes within the structure. Crucially, extracellular chromatin seems to act as the scaffold upon which the haemocytes assemble during encapsulation, showing that histones and chromatin liberated from the nucleus of ETotic cells are a highly effective way of constraining the spread of infective agents. Encapsulation, at least in shrimp, may be further aided by penaeidins, as there is a report from 2009 which showed that silencing penaeidin expression in semi-granular and granular haemocytes from $P$. monodon reduces the ability of the cells to adhere to culture plate surfaces, with a recombinant penaeidin able to restore the adhesiveness in an integrin-mediated manner (Li et al., 2010). It would interesting to see not only whether penaidins decorate extracellular chromatin traps made by shrimp haemocytes, but also determine whether encapsulation in shrimps is impaired after knock-down of penaeidin.

\section{New Tricks: Multi-functionality}

Many AMPs in mammals are known to have other functions apart from killing of bacteria (Lai and Gallo, 2009), so it is reasonable to expect that AMPs from crustaceans might also show multi-functionality.

\subsection{Proteinase inhibition}

That crustins have proteinase inhibitory effects rather than antibacterial properties has been known for some 7 years or so (Amparyup et al., 2008b; Chen et al., 2008, Jia et al., 2008; Du et al., 2010; Du et al., 2015). These crustins are almost exclusively Type III (Jia et al., 2008; Du et al., 2010). A small number of other crustins with proteinase inhibitory properties have two WAP domains (Chen et al., 2008; Du et al., 2009) so belong to the putative Type IV group. Only a few crustins show proteinase inhibitory effects and those that do rarely also exhibit microbicidal effects. However at least one crustin from $P$. monodon has been reported to exhibit both inhibitory and killing activities (Amparyup et al., $2008 b)$. Like most other proteinase inhibitory crustins, this bi-functional crustin is a Type III (Amparyup et al., 2008b). Proteinase inhibition by crustin molecules is, in some ways, not wholly unexpected as many WAP domain-containing proteins present in a range of other 
taxa, including mammals, snakes, turtles, gastropods, and bivalves are noted for their potent proteinase inhibitory effects (see review by Smith, 2011). Unfortunately, there has been little further progress in the understanding of proteinase inhibition by crustins in recent years, so there is clearly scope for this relatively neglected aspect of crustin functionality to be examined in further detail.

\subsection{Binding and opsonisation}

As it is crucial for killing, it is generally accepted that many crustacean AMPs bind bacteria or microbial cell wall components. Recent reports include Krusong et al. (2012); Du et al. (2015); Jiang et al. (2015) and Liu et al (2015). For amphipathic AMPs, e.g. penaeidins and crustins, charge will play a part in binding, as discussed by Zasloff (2002), and for ALFs the interaction with LPS appears to be mediated through the disulfide loop and the basic amino acids of the LPS-binding domain (Guo et al., 2014). However, it is unclear if binding of crustacean AMPs to bacteria also enhances their uptake by phagocytic cells, i.e. if any AMPs can act as opsonins, as proposed by Shockey et al. (2009). Until recently there was no evidence for this but a recent paper has claimed that a Type I crustin does indeed promote phagocytosis in M. japonicus (Liu et al., 2015). However, this study used an indirect approach, rather than a direct one, to assess phagocytic uptake. Briefly, the bacteria (L. anguillarum or $S$. aureus) were incubated in recombinant crustin MjCru I-1 prior to injection into shrimp, with uptake subsequently assessed by microscopy on monolayers prepared from haemocytes retrieved 15 and 30 minutes after injection. In vivo incubation, whilst in many ways representing a 'real-life' situation, does not allow for a change in the number of haemocytes in the circulation or alteration in the composition of the types present in the recovered blood. Such changes would almost certainly have occurred during the 15 and 30 minutes incubation period. There would have been some loss of haemocytes as capsules would be beginning to form at this time, and there would have been some cell lysis, ETosis or other cell deaths. Corroborative in vitro studies using separated haemocytes would help to confirm this otherwise very interesting finding. To date, opsonisation has not been recorded for any other crustins or penaedins, although $\mathrm{Li}$ and Song (2010) have produced evidence that the proline-rich domain of $P$. monodon penaeidin attracts haemocytes, especially those that are penaeidin-positive, to wound sites.

\subsection{Haematopoiesis}

Finally, recent research has produced evidence that crustacean AMPs also seem to play a role in haematopoiesis. The production of new haemocytes in most crustaceans is, in general, still incompletely understood. Most of the available information has been gained for the crayfish, $P$. leniusculus, with some work now also undertaken on shrimp, especially $P$. 
monodon. In crayfish, the process has been shown to involve prokineticin-like cytokines, named astakines, and transglutaminases (TGases). There are two astakines in crayfish: one, astakine-1, stimulates proliferation of cells within the haematopoietic tissue, while the other, astakine-2, promotes the differentiation and development of these new cells (see review by Lin \& Söderhäll, 2011). Astakine-1 is synthesized in the haemocytes and is secreted into the plasma but binds to the haematopoieic tissue via a subunit of $F_{1}$ ATP synthase present on a sub-population of cells in the haematopoietic tissue (Lin et al., 2009). $P$. monodon, by contrast, seems to have just one astakine, which, while structurally more similar to crayfish astakine 1, is functionally more akin to crayfish astakine-1 (Hsiao \& Song, 2010). In both crayfish and shrimp, TGase is present at high levels in the haematopoietic tissue and haemocytes (Lin et al., 2008; Liu et al., 2007), where it keeps the cells in an undifferentiated state (Lin et al., 2008). Absence of this protein through knock-down experiments, results in up-regulation of haematopoiesis and an increase in number of circulatory haemocytes as the immature cells within the tissue differentiate and migrate into the circulation (Lin et al., 2008; Fagutao et al., 2012). Silencing of TGase in P. monodon further affects expression of genes encoding antimicrobial proteins particularly leading to down-regulation of genes for crustin and lysozyme (Fagutao et al., 2012). Depletion of crustin (in this case, crustin 4 from $P$. monodon) and TGase significantly increase the level of astakine in the plasma (Chang et al., 2013). Conversely, elevation of crustin and TGase, for example by injection of LPS, increases astakine levels and stimulates haemocyte proliferation (Chang et al., 2013). To achieve this, crustin and TGase act together collaboratively, as similar effects do not occur if either of these is silenced individually (Chang et al., 2013). The regulation of astakine appears to occur at the translational, rather than the transcriptional, level as an increase in astakine expression, induced through silencing of crustin and TGase, is not mirrored by a change in astakine mRNA and there is no increase in crustin expression following silencing of TGase (Chang et al., 2013). Interestingly, this crustin and TGase have been shown to associate with an un-translated region (' ${ }^{3}$ UTR ${ }_{242-483}$ ) of astakine and, thus, are acting as RNA binding proteins (Chang et al., 2013). These results may help explain why crustin-like transcripts have been identified in regenerating tissues of decapods (Stoss et al., 2003; Durica et al., 2006) and why expression levels of crustin in the crab, Portunus pelagica, change over the moult cycle (Kuballa et al., 2011). Surprisingly, the level of crustin expression in this crab was found to be ca 7-8 fold higher during inter-molt than that at ecdysis, with intermediate levels recorded during the short pre-and post-moult times (Kuballa et al., 2011). This would seem counter-intuitive for a protein primarily produced for microbial killing as ecdysis would be a time of great vulnerability to opportunistic infection and the crab would need protection to ensure its survival. This raises the question as to whether or not crustins associate with 
rapidly dividing cells, especially as in mammals, WAP domain-containing proteins with antimicrobial or proteinase inhibitory effects, are highly expressed in ovary, testes and certain cancerous tissues (Bingle \& Vyakarna, 2008). Further studies on the contribution made to cell and tissue renewal by AMPs, especially crustins, are clearly warranted.

\subsection{Antiviral defence}

As far as antiviral defence is concerned, AMPs in general are not usually considered as major contributing agents. However, Havenapan et al. (2014) claim that a crustin from $P$. monodon binds Yellow Head Virus. By contrast, Hipolito et al. (2014) failed to detect any effects of crustin against White Spot Syndrome Virus. To the best of our knowledge, there is only one report of penaeidins having antiviral activity, although this was obtained only at near cytotoxic concentrations and with viruses not pathogenic for penaeid shrimp (CarrielGomes et al., 2007). Given that the expression patterns for penaeidin and crustin show very mixed response to WSSV (Table 4), there is little clear evidence that these AMPs take an active and direct role in protection against viral pathogens. However information is accumulating that ALFs might serve in this capacity. Several studies report up-regulation of ALF in both haemocytes and hepatopancreas upon WSSV challenge (Table 4), suggestive of these AMPs being involved in the host response in some way. This may be either directly through binding or indirectly. In an in vitro study, Tharntada et al. (2009) cultured haematopoietic cells with WSSV with or without recombinant PmALF-3 (a Group B ALF) and then measured viral replication by $\mathrm{qPCR}$ using the protein, VP28, as the virus marker. Interestingly, the recombinant ALF significantly reduced VP28 transcript levels with an $\mathrm{IC}_{50}$ value of $<2.5 \mu \mathrm{M}$ (Tharntada et al., 2009), revealing that ALF might have a direct effect on viral infectivity. It is unclear how ALF interacts with WSSV but a plausible explanation might be virus-binding, which would prevent them from attaching and entering their host cell.

More recent work by Li et al. (2015) tested the inhibitory activity of synthetic lipopolysaccharide binding domains from $F$. chinensis ALF (Group B) against WSSV. The authors incubated WSSV with synthetic domains before injecting the WSSV into the white prawn, Exopalaemon carinicauda, and then quantified the copy number. By substituting other amino acids for lysine, the authors demonstrated that the presence of lysine on the binding domain is essential for inhibiting the replication of the virus (Li et al., 2015). Both studies support the notion that ALF could, indeed, be a candidate antiviral agent but further work needs to undertaken on the exact way by which ALFs interfere with viral replication. Until this is clarified, the role of ALFs in defence against viral agents in crustaceans remains uncertain. 


\section{Discussion}

This review aimed to provide an overview of recent advances in our knowledge of crustaceans AMPs and to identify exciting new avenues for future research. It also attempts to show that AMPs function not only as direct killing effectors (i.e. as natural antibiotics) but are also integral to the orchestration of the host defences as whole. Figure 2 illustrates the ways in which AMPs could do this. It depicts where various immune processes involve AMPs and how these proteins might exert their effects.

From the accounts of AMPs above, it is clear that diversity of AMP types in crustaceans has markedly expanded in recent years, with ALFs, arasin-like proteins, anionic and other species-specific molecules added to the abedecary of crustins, penaidins and lysozymes that have been known for many years. There may well be more yet to be discovered as the crustacean group is very large and diverse with its members colonizing a wide range of habitats. There could, further, be more unconventional AMPs contributing to host protection awaiting discovery if we take the trouble to look. At present unconventional AMPs, such as astacins from haemocyanin and histones tend not to be included in functional studies, especially ones concerned with gene expression, because they are fragments of proteins permeating every part of the body. This makes expression measurements at the gene level of limited value. Proteomic approaches would be more useful, especially in conjunction with immunohistochemistry. That said, one reason why these 'unconventional' proteins have tended not to attract attention is that there has been uncertainty as to whether antimicrobial activity determined for them in vitro is biologically relevant in vivo. The demonstration of ETosis in crab and shrimp has now settled that question because it gives us the answer as to how they might be exposed to infective agents.

Clearly modern innovations in genomic and proteomic data gathering coupled with increased availability of high through-put instrumentation and data analyses have rapidly expanded the scope to investigate where and when AMPs are expressed during various life stages and/or following various treatments or immune challenges, making it easier to infer more about the importance of AMPs in wider aspects of immunity, development, tissue repair and other aspects of adaptive physiology. However, while gene expression studies can tell us a great deal about where and when known proteins are synthesised and which AMPs are up-regulated, it is important to understand the findings in a holistic manner. Many studies do not take into account that the number of haemocytes changes dramatically in the first $24 \mathrm{~h}$ following introduction of non-self agents or materials into the circulation. It is now very well known that there is an initial drop in the total cell count, usually with the first hour or so, as granulated haemocytes, primarily semi-granular cells, exocytose their contents 
and initiate capsule formation (see review by Smith, 2010). This is followed by a recovery period in which new haemocytes are generated in the haematopoietic tissue and repopulate the circulating pool (see reviews by Smith et al., 2010; Lin \& Söderhäll, 2011; and Roulston \& Smith, 2011). There will also be a change in the proportion of AMP-synthesizing cells post infection, with some dying in one way or another through pathogenic or toxic effects of the administered agent or material itself. Certainly, some haemocytes are sacrificed through ETosis, to aid trapping of infectious agents as discussed in Section 5.2. There is therefore a need for expression studies to include information about the composition, size and viability of the haemocyte pool in the animal at the time of sampling. Immune challenge, especially to high concentrations of infective agents or immunestimulating compounds as are usually used in many experiments, will have a profound impact on the homeostasis, with numerous genes, not just immune related ones, likely to be up- or down-regulated as the host copes with the onslaught. There may be changes in expression of genes not actually targeted for relative quantification, and therefore missed. This also means that the observed changes in AMP expression could be an indirect consequence of treatment as much as a direct one. In addition, consideration needs to be given as to whether different isoforms of the AMP under investigation respond differently to the challenge, either in the degree of change in their expression or the timing of production. As with all in vivo experiments, expression analyses will also be influenced by a range of biological factors, such as age, gender or physiological status of the animals, as well as those inherent in the experimental methodology (for instance, sample size, dose and route of administered challenge agent and statistical tests used to assess significance of the findings). Despite frequently used as evidence in current papers that a newly identified gene has antimicrobial function, up-regulation of that gene under infection conditions is not, in itself, definitive proof of antibacterial activity. Even the use of recombinant proteins for MIC analyses may not accurately reflect killing efficiency in vivo, as such proteins will not have been subjected to any post translational modifications that may occur naturally. There is also the problem as to whether the experimental conditions used in in vitro killing assays mimic the physiological conditions inside the host body.

There are still many questions about the functionality of AMPs in invertebrates, not least their multi-functionality and interaction, or not, with viral agents. From Tables 4-6, and from the data mentioned in Section 6.4, it is would seem that ALFs are likely to play some part. Clearly, these AMPs do more than participate in clotting as believed when first discovered in chelicerates. Of especial interest are the anionic ALFs belonging to Group D, as both their ability to bind LPS and to kill bacteria are weak compared to the ALFs in the other groups, as noted in Section 2.3 (above). What is needed is a better understanding of the 
interaction of ALFs with different types of virus and the consequences of knocking down the genes in healthy animals and those challenged with virus using the route of delivery more appropriate to that which would happen naturally in a shrimp pond. For WSSV, for instance this would be through cannibalisation of infected corpses.

Of the other AMPs considered in this review, the crustins still remain enigmatic. They are abundant proteins and occur widely across decapod species, yet have relatively high MIC values in in vitro assays and do not follow clear expression patterns that might be expected for a dedicated AMP. Rather, recent work, in particular that demonstrating a role for them in haematopoiesis (Section 6.3, above), coupled with the ability of some Type III and IV crustins to inhibit proteinases, points to them having a variety of roles. It would be informative to know more about their binding properties and role in regeneration or wound repair. Likewise, scygonadin is an intriguing molecule on account of its obvious association with mating and reproduction (Section 2.5 above). Are there counterparts in other crabs or members of the Decapoda? Again, knock-down experiments would provide some fascinating results.

\section{Declaration}

The authors declare they have no conflict of interest

\section{Acknowledgement}

The authors wish to thank Dr Calum Robb, Queens Medical Research Institute, Edinburgh University, Scotland, for giving us permission to use the images in Figure 1.

\section{References}

Amparyup, P, Kondo, H, Hirono, I et al. 2008a. Molecular cloning, genomic organization and recombinant expression of a crustin-like antimicrobial peptide from black tiger shrimp, Penaeus monodon. Mol. Immunol., 45, 1085-1093.

Amparyup, P, Donpudsa, S, Tassanakajon, A. 2008b. Shrimp single WAP domain (SWD)containing protein exhibits proteinase and antimicrobial activity. Dev. Comp.Immunol., 32, 1497-1509.

Antony, SP, Philip, R, Joseph, V, Singh, B. 2011. Anti-lipopolysaccharide factor and crustinIII, the anti-White Spot Virus peptides in Penaeus monodon: Control of viral infection by upregulation. Aquaculture, 319, 11-17.

Arockiaraj, J, Gnanam, AJ, Muthukrishnan, D et al. 2013a. An unconventional antimicrobial protein histone from freshwater prawn Macrobrachium rosenbergii: Analysis of immune properties. Fish Shellfish Immunol., 35, 1522-1522

Arockiaraj, J, Gnanam, A.J, Muthukrishnan, D, Gudimella, R, Milton, J, Singh, A, Muthupandian, S., Kasi, M \& Bhassu, S. 2013b. Crustin, a WAP domain containing 
antimicrobial peptide from freshwater prawn Macrobrachium rosenbergii: Immune characterization. Fish Shellfish Immunol., 34, 109-118.

Arts, JAJ, Cornelissen, FHJ, Cijsouw, T, Hermsen, T, Savelkoul., HFJ \& Stett, RJM. 2007. Molecular cloning and expression of a Toll receptor in the giant tiger shrimp. Penaeus monodon. Fish Shellfish Immunol., 23, 504-513.

Aulik, NA. Hellenbrand, KM \& Czuprynski, CJ. 2012. Mannheimia haemolytica and its leukotoxin causes macrophage extracellular trap 2 (MET) formation by bovine macrophages. Infect. Immun., 80, 1923-1933.

Babu, DT, Antony, S.P, Joseph, SP., Bright, AR, Philip, R. 2013. Marine yeast Candida aquaetextoris $\mathrm{S} 527$ as a potential immunostimulant in black tiger shrimp Penaeus monodon. J. Invert. Pathol., 112, 243-252.

Bartlett, TC, Cuthbertson, BJ, Shepard, EF, Chapman, RW, Gross, PS, Warr, GW. 2002. Crustins, homologues of an 11.5-kDa antibacterial peptide, from two species of penaeid shrimp, Litopenaeus vannamei and Litopenaeus setiferus. Mar. Biotechnol., 4, 278-293.

Bingle, CD \& Vyakarna, A. 2008. Novel innate immune functions of the whey acidic protein family. Trends Immunol., 29, 444-453.

Biswas, G, Korenaga, H, Nagamine, R., Kono, T, Shimokawa, H, Itami T. \& Sakai, M. 2012. Immune stimulant effects of a nucleotide-rich baker's yeast extract in the kuruma shrimp, Marsupenaeus japonicus. Aquaculture, 366, 40-45.

Brinkmann, V, Reichard U, Goosmann C et al. 2004. Neutrophil extracellular traps kill bacteria. Science 303, 1532-1535.

Brockton, V, Hammond, JA. \& Smith VJ. 2007. Gene characterization, isoforms and recombinant expression of carcinin, an antibacterial protein from the shore crab, Carcinus maenas. Mol. Immunol., 44, 943-949.

Brogden, G, Krimmling, T, Adamek, M, Naim, HY, Steinhagen, D. \& von Köckritz-Blickwede, M. 2014. The effect of $\beta$-glucan on formation and functionality of neutrophil extracellular traps in carp (Cyprinus carpio L.). Dev. Comp. Immunol., 44, 280-285.

Callewaert, L. \& Michiels, CW. 2010. Lysozymes in the animal kingdom. J. Biosci., 35, 127160.

Carriel-Gomes, MC, Kratz, JM, Barracco, A, Bachére, E, Barardi, CRM, \& Simões, CMO. 2007. In vitro antiviral activity of antimicrobial peptides against herpes simplex virus 1 , adenovirus, and rotavirus. Mem. Inst. Oswaldo Cruz, Rio de Janeiro, 102, 469-472.

Carty M, Goodbody R, Schroder M, Stack, J, Moynagh PN et al. 2006. The human adaptor SARM negatively regulates adaptor protein TRIF-dependent Toll-like receptor signaling. Nat Immunol., 7,1074-1081.

Chaurasia, MK, Palanismy, R, Bhatt, P, Kumaresan, V, Gnanam, AJ, Pasupuleti, M, Kasi, M, Harikrishnan, R. \& Arockiaraj, J. 2015. A prawn core histone4: Derivation of N- and Cterminal peptides and their antimicrobial properties, molecular characterization and mRNA transcription. Microbiol. Res., 170, 78-86.

Chang, Y-T, Lin, C-Y, Tsai, C-Y, Siva VS, Tsai, H-J, Song Y-L. 2013. The new face of the old molecules: Crustin Pm4 and transglutaminase Type I serving as RNPs down-regulate 
astakine-mediated hematopoiesis. PLoS ONE 8(8): e72793.

doi:10.1371/journal.pone.0072793

Chen, D, He, N \& Xu, X. 2008. Mj-DWD, a double WAP domain containing protein with antiviral relevance in Marsupenaeus japonicus. Fish Shellfish Immunol. 25, 775-781.

Choi, H, \& Lee, DG. 2014. Antifungal activity and pore forming mechanism of astacidin-1 against Candida albicans. Biochimie, 105, 58-63.

Chuammitri, P, Ostojić, J, Andreasen, CB, Redmond, SB, Lamont, SJ. \& Palić, D. 2009. Chicken heterophil extracellular traps (HETs): Novel defense mechanism of chicken heterophils. Vet. Immunol. Immunopathol., 129, 126-131.

Cui, Z, Song, C, Liu, Y, Wang, S, Wang, QL, \& Li, X. 2012. Crustins from eyestalk cDNA library of swimming crab Portunus trituberculatus: Molecular characterization, genomic organization and expression analysis. Fish Shellfish Immunol., 33, 937-945.

de la Vega E, Hall, MR, Degnan BM \& Wilson KJ. 2006. Short-term hyperthermic treatment of Penaeus monodon increases expression of heat shock protein 70 (HSP70) and reduces replication of gill associated virus (GAV). Aquaculture, 253: 1-4.

Destoumieux, D, Bulet, P, Loew, D, Van Dorsselaer, A, Rodriguez, J \& Bachère E. 1997. Penaeidins, a new family of antimicrobial peptides isolated from the shrimp Penaeus vannamei (decapoda). J. Biol. Chem., 272, 28398-28406.

Destoumieux, D, Bulet, P, Strub, J-M, Van Dorsellaer, A \& Bachère, E. 1999. Recombinant expression and range of activity of penaeidins, antimicrobial peptides from penaeid shrimp. Eur. J. Biochem. 266, 335-346.

Destoumieux, D, Muñoz, M, Cosseau, C, Rodriguez, J, Bulet, $P$, Comps, $M$ \& Bachère, $E$. 2000. Penaeidins, antimicrobial peptides with chitin-binding activity, are produced and stored in shrimp granulocytes and released after microbial challenge. J. Cell Sci., 113, 461469.

Destoumieux-Garzon, D, Saulnier, D, Garnier, J, Jouffrey, C, Bulet, P \& Bachere, E., 2001. Crustacean immunity - Antifungal peptides are generated from the $C$ terminus of shrimp hemocyanin in response to microbial challenge. J. Biol. Chem., 276, 47070-47077.

Donpudsa, S, Visetnan, S, Supungul, P, Tang, S, Tassanakajon, A \& Rimphanitchayakit, V. 2014. Type I and type II crustins from Penaeus monodon, genetic variation and antimicrobial activity of the most abundant crustinPm4. Dev. Comp. Immunol., 47, 95-103.

Du, Z-Q, Ren, Q, Zhao, X-F \& Wang, J-X. 2009. A double WAP domain (DWD)-containing protein with proteinase inhibitory activity in Chinese white shrimp, Fenneropenaeus chinensis. Comp. Biochem. Physiol. B. 154, 203-210.

Du, Z-Q, Li, X-C, Wang, Z-H., Zhao, X-F \& Wang, J-X. 2010. A single WAP domain (SWD)containing protein with antipathic relevance in red swamp crayfish, Procambarus clarkii. Fish Shellfish Immunol. 28, 134-142.

Du, Z-Q, Yuan, JJ \& Ren, D-A. 2015. A novel single WAP domain-containing protein isoform with antibacterial relevance in Litopenaeus vannamei. Fish Shellfish Immunol., 44, 478-484.

Durica,DS, Kupfer, D, Najar, F, Lai, H, Tang, Y, Griffin, K et al. 2006. EST library 
sequencing of genes expressed during early limb regeneration in the fiddler crab and transcriptional responses to ecdysteroid exposure and limb bud explants. Int,.Comp. Biol., 46:948-69.

Fagutao, FF, Maningas, MBB, Kondo, H, Aoki, T \& Hirono I. 2012. Transglutaminase regulates immune-related genes in shrimp. Fish Shellfish Immunol., 32, 711-715.

Fernandes, JMF, Kemp GD, Molle, MG \& Smith, VJ. 2002. Antimicrobial properties of H2A from skin secretions of rainbow trout, Oncorhyncus mykiss. Biochem. J., 368, 611-620.

Fuchs, TA, Abed, U, Goosmann, C et al. 2007. Novel cell death program leads to neutrophil extracellular traps. J. Cell Biol. 176, 231-241.

Garland, MA, Stillman, JH \& Tomanek, L. 2015. The proteomic response of cheliped myofibril tissue in the eurythermal porcelain crab Petrolisthes cinctipes to heat shock following acclimation to daily temperature fluctuations. J. Exp. Biol., 218, 388-403.

Gross, PS, Bartlett, TC, Browdy, CL et al. 2001. Immune gene discovery by expressed sequence tag analysis of hemocytes and hepatopancrease in the Pacific white shrimp, Litopenaeus vannamei, and the Atlantic white shrimp, L. setiferus. Dev. Comp. Immunol., $25,565-577$.

Gueguen, Y, Garnier, J, Robert, L et al. 2006. PenBase, the shrimp antimicrobial peptide penaeidin database: Sequence-based classification and recommended nomenclature. Dev. Comp. Immunol., 30, 283-288.

Guo, S, Li, S, Li, F, Zhang, X \& Xiang, J. 2014. Modification of a synthetic LPS-binding domain of anti-lipopolysaccharide factor from shrimp reveals strong structure-activity relationship in their antimicrobial characteristics. Dev. Comp. Immunol., 45, 227-232.

Hao, K, Liu, J-Y, Ling, F, Liua, X-L, Lua, L, Xia, L \& Wang, G-X. 2014. Effects of dietary administration of Shewanella haliotis D4, Bacillus cereus D7 and Aeromonas bivalvium D15, single or combined, on the growth, innate immunity and disease resistance of shrimp, Litopenaeus vannamei. Aquaculture 428-429, 141-149.

Hauton, C, Hudspith, M, Gunton, L. 2015. Future prospects for prophylactic immune stimulation in crustacean aquaculture - the need for improved metadata to address immune system complexity. Dev. Comp. Immunol., 48, 360-368.

Hauton, C, Smith, VJ. 2004. In vitro cytotoxicity of crustacean immune-stimulants for lobster (Homarus gammarus) granulocytes demonstrated using the neutral red uptake assay. Fish Shellfish Immunol., 17, 65-73.

Havanapan, P, Taengchaiyaphum, S, Bourchookarn, A, Ketterman, AJ. \& Krittanai, C. 2014. Yellow head virus binding to cell surface proteins from Penaeus monodon hemocytes. Fish Shellfish Immunol., 41, 126-136.

Herbiniere, J, Braquart-Varniera, C, Grevea, P, Strubb, J-M, Frerec, J, Van Dorsselaerb, A \& Marti, G. 2005. Armadillidin: a novel glycine-rich antibacterial peptide directed against Gram-positive bacteria in the woodlouse Armadillidium vulgare (terrestrial isopod, crustacean). Dev. Comp. Immunol., 29, 489-499.

Hipolito, SG, Shitara, A, Kondo, H \& Hirono, I. 2014. Role of Marsupenaeus japonicus crustin-like peptide against Vibrio penaeicida and white spot syndrome virus infection. Dev. Comp. Immunol., 46, 461-469. 
Hirsch, JG, 1958. Bactericidal action of histones. J. Exp. Med.,108, 925-944.

Hsiao, CY, \& Song, YL. 2010. A long form of shrimp astakine transcript: Molecular cloning, characterization and functional elucidation in promoting hematopoiesis.

Fish Shellfish Immunol., 28, 77-86.

Hu, SY, Huang, J-H \& Huang, W-T, 2006. Structure and function of antimicrobial peptide penaeidin 5 from the blak tiger shrimp Penaeus monodon. Aquaculture, 260, 61-68.

Huang, WS, Wang, KJ, Yang, M, Cai, JJ, Li, SJ, Wang, GZ, 2006. Purification and part characterization of a novel antibacterial protein Scygonadin, isolated from the seminal plasma of mud crab, Scylla serrata (Forskål, 1775). J. Exp. Mar. Biol. Ecol., 339, 37-42.

Huang, Y, Huang, X, Hou, L, Liang, A, Hiu, K-M, Ren, Q \& Wang. 2014. Molecular cloning and characterization of three novel hemocyanins from Chinese mitten crab, Eriocheir sinensis. Aquaculture, 434, 385-396.

Huang, X-D, et al. 2009. Identification and functional study of a shrimp Relish homologue. Fish Shellfish Immunol., 27, 230-238.

Huang, X-D et al. 2010. Identification and functional study of a shrimp Dorsal homologue. Dev Comp Immunol. 34, 107-113.

Jeswin, J, Anju, A., Thomas, PC, Paulton, MP \& Vijayan, KK. 2013. Survivability of Penaeus monodon during white spot syndrome virus infection and its correlation with immune related genes. Aquaculture, 380-383, 84-90

Jia, Y-P, Sun, Y-D, Wang, Z-H, Wang, Q, Wang, X-W, Zhao, X-F \& Wang, J-X. 2008. A single whey acidic protein domain (SWD)-containing peptide from fleshy prawn with antimicrobial and proteinase inhibitory activities. Aquaculture, 284, 246-259.

Jiang, H-S, Zhang, Q, Zhao, Y-R, Jia, W-M, Zhao, X-F \& Wang, J-X. 2015. A new group of anti-lipopolysaccharide factors from Marsupenaeus japonicus functions in antibacterial response. Dev. Comp. Immunol., 48, 33-42.

Kawasaki, H, Isaacson, T, Iwamuro, S \& Conlon, M. 2003. A protein with antimicrobial activity in the skin of Schlegel's green tree frog, Rhacophorus schlegelii (Racophoridae) identified as histone H2B. Biochem. Biophys. Res. Comm, 312, 1082-1086.

Kaizu, A, Fagutao, FF, Kondo, $\mathrm{H}$ et al. 2011. Functional analysis of c-type lysozyme in penaeid shrimp. J. Biol. Chem., 286, 44344-44349.

Kim, HS, Park, CB, Kim, MS \& Kim, SC. 1996. cDNA cloning and characterization of buforin I, an antimicrobial peptide: a cleavage product of histone H2A. Biochem. Biophys. Res. Commun. 229, 381-387 (1996).

Kim, M, Jeon, J-M, Oh, W-C, Kim, YM, Lee, DS, Kang, K-C \& Kim, H-W. 2012. Molecular characterization of three crustin genes in the morotoge shrimp, Pandalopsis japonica. Comp. Biochem. Physiol. B, 163, 161-171.

Kono, T, Fall, J, Korenaga, $\mathrm{H}$ et al. 2014. Recombinant VP28 produced by cell-free technique confers protection in Kuruma shrimp (Marsupenaeus japonicas) against White Spot Syndrome Virus. Turkish J. Fish Aquatic Sci., 14, 547-555.

Krusong, K, Poolpipat, P, Supungul, P \& Tassanakajon, A. 2012. A comparative study of 
antimicrobial properties of crustin Pm1 and crustin $\mathrm{Pm} 7$ from the black toger shrimp Penaeus monodon. Dev. Comp. Immunol., 36, 208-215.

Kuballa, AV, Holton, TA, Paterson, B \& Elizur, A. 2011. Moult cycle specific differential gene expression profiling of the crab, Portunus pelagicus . BMC Genomics 12, 147-165.

Lai Y, \& Gallo, R. 2009. AMPed up immunity: how antimicrobial peptides have multiple roles in immune defense. Trends Immunol., 30, 131-141.

Lan, J-F et al. 2013. Characterisation of an immune deficiency homolog (IMD) in shrimp (Fenneropenaeus chinensis) and crayfish (Procambarus clarkii). Dev. Comp. Immunol., 41, 608-617.

Lee, SY, Lee, BK \& Soderhall, K. 2003. Processing of an antibacterial peptide from haemocyanin of the freshwater crayfish Pacifastacus leniusculus. J. Biol. Chem., 278, 7927-7933.

Li, CY, Yan, HY \& Song, YL. 2010. Tiger shrimp (Penaeus monodon) penaeidin possesses cytokine features to promote integrin-mediated granulocyte and semi-granulocyte adhesion. Fish Shellfish Immunol., 28, 1-9.

L,i CY \& Song, YL. 2010. Proline-rich domain of penaeidin molecule exhibits autocrine feature by attracting penaeidin-positive granulocytes toward the wound-induced inflammatory site. Fish Shellfish Immunol., 29, 1044-1052.

Li, F, Wang, L, Qiu, L, Zhang, H, Gai, Y \& Song, L. 2012. A double WAP domain-containing protein from Chinese mitten crab Eriocheir sinensis with antimicrobial activities against Gram-negative bacteria and yeast. Dev. Comp. Immunol., 36, 183-190.

Li, S, Guo, S, Li, F \& Xiang, J. 2014. Characterization and function analysis of an antilipopolysaccharide factor (ALF) from the Chinese shrimp Fenneropenaeus chinensis. Dev. Comp. Immunol., 46, 349-355.

Li, S, Guo, S, Li, F \& Xiang, J. 2015. Functional diversity of anti-lipopolysaccharide factor isoforms in shrimp and their characters related to antiviral activity. Mar. Drugs, 13, 26022616.

Lin, X, Kim, Y-A, Lee, BL, Söderhäll, K \& Söderhäll, I. 2009. Identification and properties of a receptor for the invertebrate cytokine astakine, involved in hematopoiesis. Exp. Cell Res., $315,1171-1180$.

Lin X, Söderhäll K \& Söderhäll I. 2008. Transglutaminase activity in the haemopoietic tissue of a crustacean, Pacifastacus leniusculus, importance in hemocyte homeostasis. BMC Immunol. 9, 58.

Lin, X \& Söderhäll I. 2011. Crustacean hematopoiesis and the astakine cytokines. Blood,117, 6417-6424.

Liu, J, Yu, Y, Li, F, Zhang, X \& Xiang, J. 2014. A new anti-lipopolysaccharide factor (ALF) gene with its SNP polymorphisms related to WSSV-resistance of Litopenaeus vannamei. Fish Shellfish Immunol., 39, 24-33.

Liu, N, Lan, J-D, Sun, J-J, Jis, W-M, Zhao, X-F \& Wang, J-X. 2015. A novel crustin from Marsupenaeus japonicus promotes hemocyte phagocytosis. Dev. Comp. Immunol., 49, 313-322. 
Liu Y-C, Li, F-H. Wand, B et al., 2007. A transglutaminase from Chinese shrimp (Fenneropenaeus chinensis), full-length cDNA cloning, tissue localization and expression profile after challenge. Fish Shellfish Immunol., 22, 576-588.

Liu, Y, Cui, Z, Li, X, Song, C, Shi, G, Wang, C. 2013. Molecular cloning, genomic structure and antimicrobial activity of PtALF7, a unique isoform of anti-lipopolysaccharide factor from the swimming crab Portunus trituberculatus. Fish Shellfish Immunol., 34, 652-659.

Liu, Z, Cui, W, Luan, C, Song, QN, Wang, S \& Li, Q. 2010. Three isoforms of antilipopolysaccharide factor identified from eyestalk cDNA library of swimming crab Portunus trituberculatus. Fish Shellfish Immunol., 30, 583-591.

Loc, NH, MacRae, TH, Musa, N, bin Abdullah, MDD, Wahid, MEA \& Sung, YY. 2013. Nonlethal heat shock increased Hsp70 and immune protein transcripts but not Vibrio tolerance in the White-Leg Shrimp. PLoS ONE 8(9): e73199. doi:10.1371/journal.pone.0073199.

Maeda, M, Shibata, A, Biswas, G, Korenaga, H, Kono, T, Itami, T \& Sakai, M. 2013. Isolation of lactic acid bacteria from Kuruma shrimp (Marsupenaeus japonicus) intestine and assessment of immunomodulatory role of a selected strain as probiotic. Mar.

Biotechnol., 16, 181-192.

Mai, W \& Hu, C. 2009. cDNA cloning, expression and antibacterial activity of lysozyme C in the blue shrimp (Litopenaeus stylirostris). Prog. Nat. Sci., 19, 837-844.

Mekata, T., Kono, T, Yoshida, Sakai, M \& Itami, T. 2008. Identification of cDNA encoding Toll receptor MjToll gene from the kuruma shrimp, Marsupenaeus japonicas. Fish Shellfish Immunol., 24, 122-133.

Mekata, T, Sudhakaran, S, Okugawa, T, Kono, Sakai, M \& Itami, T. 2010. Molecular cloning and transcriptional analysis of a newly identified anti-lipopolysaccharide factor gene in kuruma shrimp, Marsupenaeus japonicus. Lett. Appl. Microbiol., 50, 112-119.

Meng, Q, Hou, L, Zhao, Y, Huang, X, Huang, Y, Xia, S, Gu, W \& Wang, W. 2014. iTRAQbased proteomic study of the effects of Spiroplasma eriocheiris on Chinese mitten crab Eriocheir sinensis hemocytes. Fish Shellfish Immunol., 40, 182-189.

Montero-Alejo, V, Acosta-Alba, J, Perdomo-Morales, R, Perera, E, Hernández-Rodríguez, EW, Estrada, MP \& Porto-Verdecia, M. 2012. Defensin like peptide from Panulirus argus relates structurally with beta defensin from vertebrates. Fish Shellfish Immunol. 33, 872879.

Mu, C. Zheng, P, Zhao, J, Wang, L, Qiu, L, Zhang, H, Gai, Y \& Song, L. 2011. A novel type III crustin (CrusEs2) identified from Chinese mitten crab Eriocheir sinensis. Fish Shellfish Immunol., 31, 142-147.

Nayak, S, Singh, SK, Ramaiah, N \& Sreepada, RA. 2010. Identification of upregulated immune-related genes in Vibrio harveyi challenged Penaeus monodon postlarvae. Fish Shellfish Immunol., 29, 544-549.

Nayak, S, Ajay, KM, Ramaiah, N, Meena, RM \& Sreepada, RA. 2011. Profiling of a few immune responsive genes expressed in postlarvae of Fenneropenaeus indicus challenged with Vibrio harveyi D3. J. Invert. Pathol., 107, 168-172.

Ng, TH, Wu, M-H, Chang, S-H, Aoki, T \& Wang, H-C. 2015. The DNA fibres of shrimp 
hemocyte extracellular traps are essential for the clearance of Escherichia coli. Dev. Comp. Immunol., 48, 229-233.

Noga, EJ, Stone, KL, Wood, A, Gordon, WL \& Robinette, D. 2011. Primary structure and cellular localization of callinectin, an antimicrobial peptide from the blue crab. Dev. Comp. Immunol., 35, 409-415.

Ohashi, K, Niwa, M, Nakamura, T et al. 1982. Anti-LPS factor in the horseshoe crab, Tachypleus tridentatus - its haemolytic activity on the red blood cell sensitized with lipopolysaccharide. FEBS Lett., 176, 207-210.

Palić, D, Ostojić, J, Andreasen CB, \& Roth, JA. 2007. Fish cast NETs: Neutrophil extracellular traps are released from fish neutrophils. Dev. Comp. Immunol., 31, 805-816.

Pan, L, Yue, F, Miao, J. et al. 2010. Molecular cloning and characterization of a novel ctype lysozyme gene in swimming crab Portunus trituberculatus. Fish Shellfish Immunol., 29, 286-292.

Park, CB, Yi, KS, Matsuzaki, K, Kim, MS \& Kim, SC. 2000. Structure-activity analysis of buforin II, a histone $\mathrm{H} 2 \mathrm{~A}$-derived antimicrobial peptide: the proline hinge is responsible for the cell-penetrating ability of buforin II. Proc. Natl Acad. Sci. USA 97, 8245-8250.

Paulsen, VS, Blencke, H-M, Benincasa, M, Haug, T, Eksteen, JJ, Styrvold, OB, Scocchi, M \& Stensvåg, K. 2013. Structure-activity relationships of the antimicrobial peptide arasin 1and mode of action studies of the n-terminal, proline-rich region. PLoS One, 8, e53326.

Patat, SA, Carnegie, RB, Kingsbury, C, Gross, PS, Chapman, R \& Schey, KL. 2004. Antimicrobial activity of histones from the Pacific white shrimp. Eur. J. Biochem., 271, 48254833.

Peregrino-Uriarte, AB, Muhlia-Almazan, AT, Arvizu-Flores, AA. 2012. Shrimp invertebrate lysozyme i-lyz: Gene structure, molecular model and response of $c$ and i lysozymes to lipopolysaccharide (LPS). Fish Shellfish Immunol., 32, 230-236.

Phillips, A, Anderson, VL, Robertson, EJ, Secombes, CJ, \& van West, P. 2007. New insights into animal pathogenic oomycetes. Trends Microbiol., 16, 13-19.

Pisuttharachai, D, Yasuike, M, Aono, H, Yano, Y, Murakami, K, Kondo, H, Aoki, T, Hirono, I. 2009. Characterization of two isoforms of Japanese spiny lobster Panulirus japonicus defensin cDNA. Dev. Comp. Immunol., 33, 434-438.

Qin, T, Zhao, X, Luan, $\mathrm{H}$ et al., 2015. Identification, expression pattern and functional characterization of $A S-M y D 88$ in bacteria challenge and during different development stages of Artemia sinica. Dev. Comp. Immunol. 50, 9-18.

Qiu, C, Liu, JS, Wang, B, Jiang, K, Sun, S, Meng, X, Luo, Z \& Wang, L. 2014. Molecular cloning of hemocyanin cDNA from Fenneropenaeus chinensis and antimicrobial analysis of two C-terminal fragments. Mar. Biotechnol., 16, 46-53.

Rainer, J \& Brouwer, M. 1993. Hemocyanin synthesis in the blue crab Callinectes sapidus. Comp. Biochem. Physiol. B., 104, 69-73.

Relf, J.M, Chisholm, JR.S, Kemp, GD. \& Smith, VJ. 1999. Purification and characterization of a cysteine-rich 11.5-kDa antibacterial protein from the granular haemocytes of the shore crab, Carcinus maenas. Eur. J. Biochem., 264, 350-357. 
Ren, Q, Zhang, Z, Li, X-C, Jie, D, Hui, K-M, Zhang, C-Y \& Wang, W. 2012. Three different anti-lipopolysaccharide factors identified from giant freshwater prawn, Macrobrachium rosenbergii. Fish Shellfish Immunol., 33, 766-774.

Robb, CT, Dyrynda, EA, Gray, RD, Rossi, AG \& Smith, VJ. 2014. Invertebrate phagocyte traps show that chromatin is an ancient defence weapon. Nature Comms, 5:4627. DOI: $10.1038 /$ ncomms5627.

Rolland, JL, Abdelouahab, M, Dupont, J, Lefevre, F, Bachere, E \& Romestand, B. 2010. Stylicins, a new family of antimicrobial peptides from the Pacific blue shrimp Litopenaeus stylirostris. Mol. Immunol., 47, 1269-1277.

Rosa, RD, Vergnes, A, de Lorgeril, J et al. 2013. Functional divergence in shrimp antilipopolysaccharide factors (alfs): from recognition of cell wall components to antimicrobial activity. PLoS One, 8, e67937.

Roulston, C \& Smith, VJ. 2011. Isolation and in vitro characterisation of prohaemocytes from the spider crab, Hyas araneus (L.) Dev. Comp. Immunol., 35, 537-544.

Rungrassamee, W, Kingcha, Y, Srimarut, Y. 2014. Manno-oligosaccharides from copra meal improves survival of the Pacific white shrimp (Litopenaeus vannamei) after exposure to Vibrio harveyi. Aquaculture, 434, 403-410.

Schnapp, D, Kemp, GD, \& Smith, VJ. 1996. Purification and characterization of a prolinerich antibacterial peptide, with sequence similarity to bactenecin- 7, from the haemocytes of the shore crab, Carcinus maenas. Eur. J. Biochem., 240, 532-539.

Shanthi, S \& Vaseeharan, B. 2012. cDNA cloning, characterization and expression analysis of a novel antimicrobial peptide gene penaeidin-3 (Fi-Pen3) from the haemocytes of Indian white shrimp Fenneropenaeus indicus. Microbiol. Res., 167, 127-134.

Shen, W, Mao, Y, Ge, S. et al. 2010. cDNA cloning, characterization and mRNA expression of a hyastatin-like gene from swimming crab Portunus trituberculatus. Oceanol. Limnol. Sinica, 41, 246-253.

Shi, X-Z, Zhang, R-R, Jia, Y-P, Zhao, X-F, Yu, X-Q \& Wang, J-X. 2009. Identification and molecular characterization of a Spätzle-like protein from Chinese shrimp (Fenneropenaeus chinensis). Fish Shellfish Immunol., 27, 610-617.

Shi, X-Z, Li, X-C, Wang, S, Zhao, X-F \& J-X Wang. 2010. Transcriptome analysis of hemocytes and hepatopancreas in red swamp crayfish, Procambarus clarkii, challenged with White Spot Syndrome Virus. Invert. Survival J., 7, 119-131.

Shi, X-Z, Zhao, X-F \& Wang, J-W. 2014. A new type antimicrobial peptide astacidin response in red swamp crayfish Procambarus clarkii. Dev. Comp. Immunol., 43, 121-128.

Shockey, JE, O'Leary, NA, de la Vega, E, Browdy, CL. Baatz, JE \& Gross, PS. 2009. The role of crustins in Litopenaeus vannamei in response to infection with shrimp pathogens: An in vivo approach. Dev. Comp. Immunol., 33, 668-673.

Smith, VJ. 2010. Immunology of invertebrates: Cellular. In: Encyclopedia of Life Sciences (ELS). John Wiley \& Sons, Ltd: Chichester. DOI: 10.1002/9780470015902.a0002344.pub2.

Smith, VJ. 2011. Phylogeny of whey acidic protein (WAP) four disulfide core proteins and their role in lower vertebrates and invertebrates. Biochem. Soc. Trans., 39, 1403-1408. 
Smith, VJ \& Fernandes, JMO. 2008. Non-specific antimicrobial proteins of the innate system. In: Fish Defences vol 1: Immunology. Eds, Zaccone, G, Meseguer, J, GarcíaAlaya A. \& Kapoor, BG. Science Publishers, Enfield NJ, Jersey \& Plymouth, 241-275.

Smith, VJ, Brown, JH, Hauton, C. 2003. Immunostimulation in crustaceans: does it really protect against infection? Fish Shellfish Immunol., 15, 71-90.

Smith, VJ, Fernandes, JMO, Kemp, GD \& Hauton, C. 2008. Crustins: Enigmatic WAP domain-containing antibacterial proteins from crustaceans. Dev. Comp. Immunol., 32, 785772 .

Smith, VJ, Roulston, C, \& Dyrynda, EA. 2010. The shrimp immune system. In: The Shrimp Book, ed. Alday V Nottingham University Press, UK, pp 89-148.

Song, Y-L \& Li, CY. 2014. Shrimp immune system. Special focus on penaeidin. J. Mar Sci. Technol., 22, 1-8.

Soonthornchai, W, Rungrassamee, W, Karoonuthaisiri, N, Jarayabhand, P, Klinbunga, S, Soderhall, K, Jiravanichpaisal, P. 2010. Expression of immune-related genes in the digestive organ of shrimp, Penaeus monodon, after an oral infection by Vibrio harveyi. Dev. Comp. Immunol., 34, 19-28.

Sperstad, SV, Haug, T, Vasskog, T, et al. 2009. Hyastatin, a glycine-rich multi-domain antimicrobial peptide isolated from the spider crab (Hyas araneus) hemocytes. Mol. Immunol., 46, 2604-2612.

Sperstad, SV, Smith, VJ \& Stensvåg, K. 2010. Expression of antimicrobial peptides from Hyas araneus haemocytes following bacterial challenge in vitro. Dev. Comp. Immunol., 34, 618-624.

Sperstad, SV, Haug, T, Blencke, H-M, Styrvold, OB, Li, C \& Stensvåg, K. 2011. Antimicrobial peptides from marine invertebrates: Challenges and perspectives in marine antimicrobial peptide discovery. Biotechnol. Advances, 29, 519-530.

Stensvåg, K, Haug, T, Sperstad, SV, Rekdal, O, Indrevoll, B \& Styrvold, OB. 2008. Arasin 1, a proline-arginine-rich antimicrobial peptide isolated from the spider crab, Hyas araneus. Dev. Comp. Immunol., 32, 275-285.

Stoiber, W, Obermayer, A, Steunbacher, P \& Krautgartner, W-D. 2015. The role of reactive oxygen species (ROS) in the formation of extracellular traps (ETs) in humans. Biomolecules. 5, 702-723; doi:10.3390/biom5020702

Stoss, TD, Nickell, MD, Hardin, D, Derby, CD \& McClintock, TS. 2003. Inducible transcript expressed by reactive epithelial cells at sites of olfactory sensory neuron proliferation. $J$. Neurobiol. 58, 355-368.

Sudheer, NS, Poulose, G, Thomas, A, Viswanath, K, Kulkarni, A, Narayanan, RB, Philip, R \& Singh, ISB. 2015. Expression profile of bio-defense genes in Penaeus monodon gills in response to formalin inactivated white spot syndrome virus vaccine. Antiviral Res., 117, 6068.

Sun, C, Xu, W-T, Zhang, H-W, Dong, L-P, Zhang, T, Zhao, X.-F \& Wang, J-X, 2011. An anti-lipopolysaccharide factor from red swamp crayfish, Procambarus clarkii, exhibited antimicrobial activities in vitro and in vivo. Fish Shellfish Immunol., 30, 295-303. 
Sun, J, Wang, L, Wang, B, Guo, Z, Liu, M, Jiang, K \& Luo, Z. 2007. Purification and chsraterisation of a natural lectin from the serum of the shrimp, Litopenaeus vanamei. Fish Shellfish Immunol., 23, 292-299.

Sun, W, Wan, W, Zhua, S, Wang, S, Wang, S, Wen, X, Zheng, H, Zhang, Y \& Lia, S, 2015. Characterization of a novel anti-lipopolysaccharide factor isoform (SpALF5) in mud crab, Scylla paramamosain. Mol. Immunol., 64, 262-275.

Sun, Y-D, Fu, L-D, Jia, Y-P et al. 2008. A hepatopancreas specific C-type lectin from the Chinese shrimp Fenneropenaeus chinensis exhibits antimicrobial activity. Mol. Immunol., 45, 348-361.

Supungul, P, Vichien, R, Aoki, T et al. 2010. Molecular characterization and expression analysis of a c-type and two novel muramidase-deficient i-type lysozymes from Penaeus monodon. Fish Shellfish Immunol., 28, 490-498.

Sung YY, Van Damme EJM, Sorgeloos P \& Bossier P. 2007. Non-lethal heat shock protects gnotobiotic Artemia franciscana larvae against virulent Vibrios. Fish Shellfish Immunol., 22, 318-326.

Sung, YY \& MacRae, TH. 2011. Heat shock proteins and disease control in aquatic organisms. J. Aquacult, Res. Dev. S2:006. doi:10.4172/2155-9546.S2-006

Taju, G, Madan, N, Majeed, SA, Kumar, TJ, Thamizhvanan, S, Otta, SK \& Hameed, ASS. 2015. Immune responses of whiteleg shrimp, Litopenaeus vannamei (Boone, 1931), to bacterially expressed dsRNA specific to VP28 gene of White Spot Syndrome Virus. J. Fish Dis., 38, 451-465.

Tanaka, S, Nakamura, T, Morita, T \& Iwanaga, S. 1982. Limulus anti-LPS factor: an anticoagulant which inhibits the endotoxin mediated activation of Limulus coagulation system. Biochem. Biophys. Res. Commun., 105, 717-723.

Tassanakajon, A, Amparyup, P, Somboonwiwat, K \& Supungul, P. 2011. Cationic antimicrobial peptides in penaeid shrimp. Mar. Biotechnol., 12, 487-505.

Tassanakajon, A, Somboonwiwat, K \& Amparyup, P. 2015. Sequence diversity and evolution of antimicrobial peptides in invertebrates. Dev. Comp. Immunol., 48, 324-341.

Tharntada, S, Ponprateep, S, Somboonwiwat, K et al. 2009. Role of antilipolysaccharide factor from the blacl tiger shrimp Penaeus monodon in protection from White Spot Syndrome Virus infection. J. Gen Virol., 90, 1491-1498.

Touch, V, Hayakawa, S \& Saitoh, K. 2004. Relationships between conformational changes and antimicrobial activity of lysozyme upon reduction of its disulfide bonds. Food Chem., $84,421-428$.

von Kockritz-Blickwede, M, Goldmann, O, Thulin, P, Heinmann,K., Norrby-Teglund, A, Rohde, M \& Medina, E. 2008. Phagocytosis independent antimicrobial activity of mast cells by means of extracellular trap formation. Blood, 111, 3070-3080.

Vidya, R, Paria, A, Deepika, A et al. 2014. Toll-like receptor of mud crab, Scylla serrata: molecular characterization, ontogeny, and functional expression analysis following exposure and bacterial and viral infections. Mol. Biol. Rep., 41, 6865-6877. 
Wang, P-H, Liang, J-P, Gu, Z-H, Wan, DH et al. 2012. Molecular cloning, characterization and expression analyses of two novel Tolls (LvToll2 and LvToll3) and three putative Spätzle-like ligands (LvSpz1-3) from Litopenaeus vannamei. Dev. Comp. Immunol., 36, 359-371.

Wang, P-H, Gu, Z-H, Wan, D-H et al. 2013. Litopenaeus vannamei Sterile-Alpha and Armadillo Motif containing protein (LVSARM) is involved in regulation of penaeidins and anti-lipopolysaccharide factors. PLoS ONE 8(2): e52088. doi:10.1371/journal.pone.0052088

Wang, X-W, Xu, WT, Zhang, XW, Zhao, XF, Yu, XQ \& Wang, JX, 2009a. A C-type lectin is involved in the innate immune response of Chinese white shrimp. Fish Shellfish Immunol. 27, 556-562.

Wang, X-W, Zhang, XW, Xu, WT, Zhao, XF \& Wang, JX, 2009b. A novel C-type lectin (FcLec4) facilitates the clearance of Vibrio anguillarum in vivo in Chinese white shrimp. Dev. Comp. Immunol. 33, 1039-1047.

Wang, X-W \& Wang, J-X. 2013. Diversity and multiple functions of lectins in shrimp immunity. Dev. Comp. Immunol,, 39, 27-38.

Wang, Z, Chen, Y-H, Dai, Y-J et al., 2015. A novel vertebrate Toll-like receptor counterpart regulating the antimicrobial peptides in the freshwater crayfish, Procambarus clarkii. Fish Shellfish Immunol., 43, 219-229.

Webster, SJ, Daigneault, M, Bewley, MA et al. 2010. Distinct cell death programs in monocytes regulate innate responses following challenge with common causes of invasive bacterial disease. J. Immunol. 185, 2968-2979.

Wilson, W, Lowman, D, Antony, SP, Puthumana, J, Singh ISB \& Philip, R. 2015. Immune gene expression profile of Penaeus monodon in response to marine yeast glucan application and white spot syndrome virus challenge. Fish Shellfish Immunol., 43, 346-356.

Woramongkolchaia, N, Supungul, P \& Tassanakajon, A. 2011. The possible role of penaeidin 5 from the black tiger shrimp, Penaeus monodon, in protection against viral infection. Dev. Comp. Immunol., 35, 530-536.

Xu, W-F, Qiao, K, Huang, S-P, Peng, H, Huang, W-S, Chen, B, Chen, F-Y, Chen, JB \& Wang, K-J. 2011. Quantitative gene expression and in situ localization of scygonadin potentially associated with reproductive immunity in tissues of male and female mud crabs, Scylla paramamosain. Fish Shellfish Immunol., 31, 243-251.

Yang, L-S, Yin Z-X, Liao, J-X et al., 2007. A Toll receptor in shrimp. Mol. Immunol., 44, 1999-2008.

Yang, C, Zhang, J, Li, F et al. 2008. A Toll receptor from Chinese shrimp Fenneropenaeus chinensis is responsive to Vibrio anguillarum infection. Fish Shellfish Immunol., 24, 564-574.

Yang, CC, Lu, C-L, Chen, S, Liao, W-L, Chen, S-N, 2015. Immune gene expression for diverse haemocytes derived from pacific white shrimp, Litopenaeus vannamei. Fish Shellfish Immunol. 44, 265-271.

Yedery, RD \& Reddy, KVR. 2009. Purification and characterization of antibacterial proteins from granular hemocytes of Indian mud crab, Scylla serrata. Acta Biochim. Pol., 56, 71-82. 
Yousefi, S, Gold, JA, Andina, $\mathrm{N}$ et al. 2008. Catapult-like release of mitochondrial DNA by eosinophils contributes to antibacterial defense. Nat. Med., 14, 949-953.

Zasloff, M. 2002. Antimicrobial peptides of multicellular organisms. Nature, 415, 389-395.

Zhao, K, Wu, H, Lu, H, Li, G \& Huang, Q. 2013a. LAMP: A data-base linking antimicrobial peptides. PLOS ONE, 8(6): e66557. doi:10.1371/journal.pone.0066557

Zhao, L, Yin, B, Liu, Q \& Rong, CAO. 2013b. Purification of antimicrobial peptide from Antarctic krill (Euphausia superba) and its function mechanism. J. Ocean Univ. China, 12, 484-490.

Zhao, H-X, Cao, J-M, Wang, A-L, Huang, Y-H, Li, G-L, Lan, H-B. 2012. Effects of dietary $\beta-$ 1,3-glucan on expression of immune-related genes of Litopenaeus vannamei exposed to nitrite-N . J. World Aquaculture Soc., 43, 400-410.

Zhang, H-W, Sum C, Sun, S-S, Zhao, X-F, Wang, J-X. 2010a. Functional analysis of two invertebrate lysozymes from red swamp crayfish Procambarus clarkii. Fish Shellfish Immunol., 29, 1066-1072.

Zhang, JQ, Li, FH, Wang, ZZ. \& Xiang, JH, 2007. Cloning and recombinant expression of a crustin-like gene from Chinese shrimp, Fenneropenaeus chinensis. J. Biotechnol., 127, 605-614.

Zhang, S, Qiu, W, Chen, Y. et al., 2015b. Flightless-I (Flil) is a potential negative regulator of the Toll pathway in Litopenaeus vannamei. Fish Shellfish Immunol., 42, 413-425.

Zhang, Y, Wang, L, Wang, L, Yang, J, Gaia, Y, Qiua, L \& Song, L. 2010b. The second antilipopolysaccharide factor (EsALF-2) with antimicrobial activity from Eriocheir sinensis. Dev. Comp. Immunol., 34, 945-952.

Zhang, Z \& Zhu, S. 2012. Comparative genomics analysis of five families of antimicrobial peptide-like genes in seven ant species. Dev. Comp. Immunol., 38, 262-274.

Zhang, Z, Li, S, Xie, C, Zhou, L, Li, C, Liu, W \& Wen, X. 2015a. Innate immune response and gene expression of Scylla paramamosain under Vibrio parahaemolyticus infection. Aqua. Res., 46, 462-471. 


\section{Figure legends}

Figure 1. In vitro entrapment of bacteria on externalised chromatin from crab, $C$. maenas, haemocytes through ETosis. (a): Confocal image of $C$. maenas haemocytes incubated for $24 \mathrm{~h}$ with Listonella anguillarum in vitro and stained with the nuclear dye, Sytox Green, and then fixed in paraformaldehyde before scrutiny. The bacteria have induced some of the cells to expel extruded strands or clouds of Sytox-positive material (chromatin) from the nucleus to the exterior environment. The round stained structures are the nuclei of non-ETotic cells. (b): Phase contrast image of the same cells showing strings of bacteria; clusters and some intact haemocytes. (c): Merge of a and b. The extruded nuclear material co-localises with the strings of bacteria (white arrows), showing that they are trapped on the chromatin. Scale bars $=49.8 \mu \mathrm{m}$. Images courtesy of Dr Calum Robb.

Figure 2. Generalised schematic summarising the various ways by which AMPs in crustaceans contribute to host defence in vivo. This graphic depicts the release of AMPs from haemocytes, their delivery to sites of infection, possible role in phagocytosis and involvement in haematopoiesis. AMPs $=$ antimicrobial peptides $\mathrm{ROS}=$ reactive oxygen species generated by the respiratory burst; $\mathrm{H}$ cells = hyaline haemocytes; $\mathrm{SG}$ cells $=$ semi granular haemocytes; G cells = granular haemocytes; TGase - transglutaminase; HTP = haematopoietic tissue. 
Figure 1
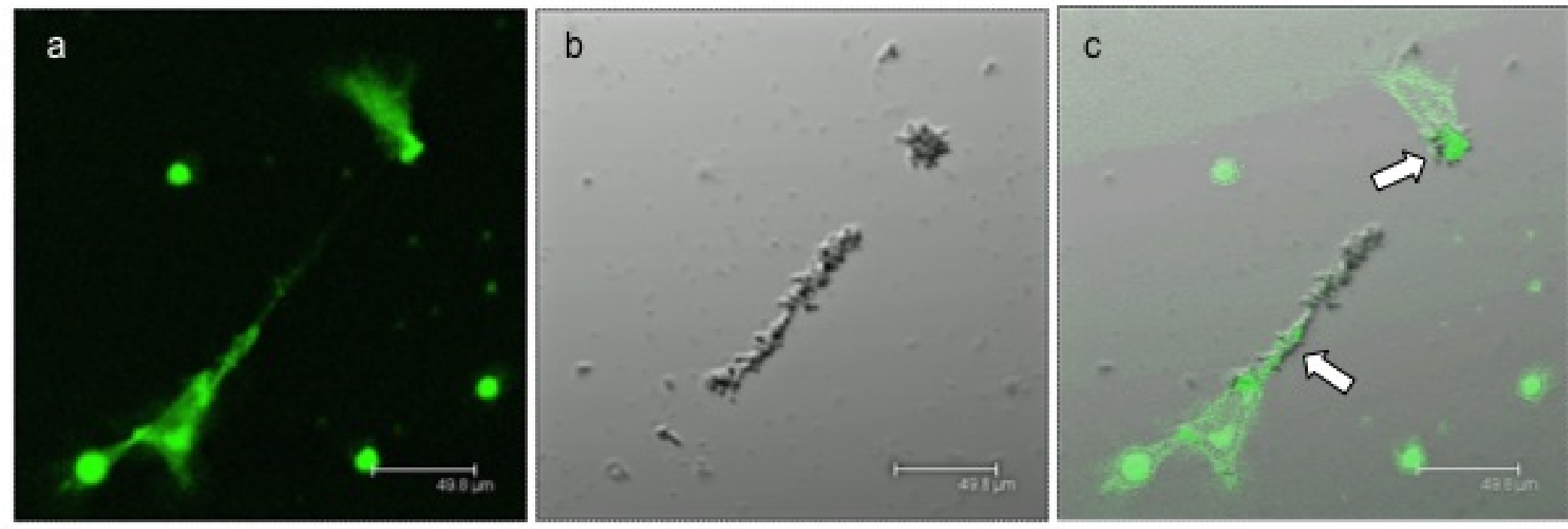
Figure 2

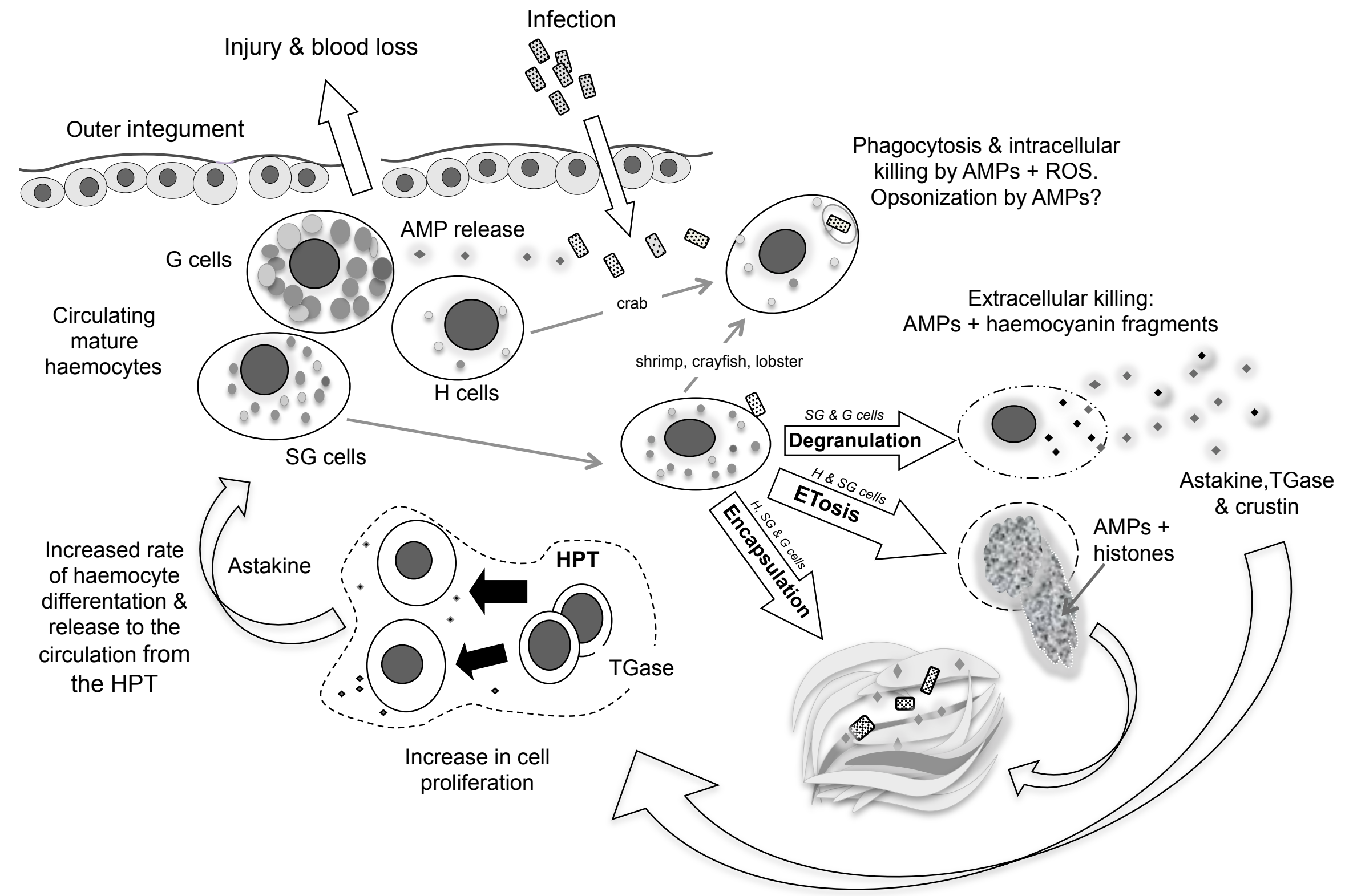


Table 1. Families of antibacterial proteins identified in crustaceans

\begin{tabular}{|c|c|c|c|c|}
\hline Family & $\mathrm{Cla}$ & sses/Types & Function(s) & Key reference \\
\hline \multirow{4}{*}{$\begin{array}{l}\text { Crustins } \\
(7-14 \mathrm{kDa})\end{array}$} & 1 & $\begin{array}{l}1 \text { WAP domain + cys } \\
\text { rich domain }\end{array}$ & \multirow[t]{4}{*}{$\begin{array}{l}\text { Antibacterial or } \\
\text { proteinase inhibitors }\end{array}$} & \multirow[t]{4}{*}{$\begin{array}{l}\text { Smith et al., } 2008 \\
\text { Smith, } 2011\end{array}$} \\
\hline & II & $\begin{array}{l}1 \text { WAP domain,+ cys- } \\
\text { rich \& gly-rich domains }\end{array}$ & & \\
\hline & III & $\begin{array}{l}1 \text { WAP domain }+1 \\
\text { pro/arg-rich region. No } \\
\text { cys- or gly-rich domains }\end{array}$ & & \\
\hline & IV & 2 WAP domains & & \\
\hline \multirow{2}{*}{$\begin{array}{l}\text { Penaeidins } \\
(5-7 \mathrm{kDa})\end{array}$} & \multicolumn{2}{|c|}{$\begin{array}{l}\text { Classes relate to primary } \\
\text { sequence variation and } \\
\text { phylogenetic analysis }\end{array}$} & $\begin{array}{l}\text { Antibacterial, chitin- } \\
\text { binding, possible } \\
\text { chemoattractants }\end{array}$ & Song \& Li, 2014 \\
\hline & \multicolumn{2}{|c|}{$\begin{array}{l}\text { Four classes, PEN-2, PEN- } \\
3, \text { PEN-4, PEN-5 }\end{array}$} & & \\
\hline \multirow{7}{*}{$\begin{array}{c}\text { Anti- } \\
\text { lipopolysaccharide } \\
\text { factors (ALFs) } \\
(10-12 \mathrm{kDa})\end{array}$} & \multirow{2}{*}{\multicolumn{2}{|c|}{$\begin{array}{l}\text { Classes relate primarily to } \\
\text { variations in LPS-binding } \\
\text { site }\end{array}$}} & \multirow{7}{*}{$\begin{array}{l}\text { Antibacterial, antiviral, } \\
\text { antifungal, bind LPS }\end{array}$} & \multirow{7}{*}{$\begin{array}{l}\text { Rosa et al., } 2013 \\
\text { Jiang et al., } 2015\end{array}$} \\
\hline & & & & \\
\hline & $A$ & Anionic/cationic & & \\
\hline & B & Cationic & & \\
\hline & C & Cationic & & \\
\hline & $\mathrm{D}$ & Anionic & & \\
\hline & $E$ & Cationic & & \\
\hline \multirow{3}{*}{$\begin{array}{l}\text { Lysozymes } \\
\qquad(14 \mathrm{kDa})\end{array}$} & \multicolumn{2}{|c|}{ Muramidases } & Antibacterial & Zhang et al $2010 a$ \\
\hline & \multicolumn{2}{|c|}{ C (chicken) -type } & & \\
\hline & \multicolumn{2}{|c|}{ I (invertebrate)- type } & & \\
\hline Histones & \multirow{2}{*}{\multicolumn{2}{|c|}{$\begin{array}{l}\text { Nuclear proteins } \\
\mathrm{H} 2 \mathrm{~A} \& \mathrm{~B}, \mathrm{H} 3, \mathrm{H} 4\end{array}$}} & Antibacterial & Patat et al., 2004 \\
\hline$(11-15 \mathrm{kDa})$ & & & & \\
\hline
\end{tabular}


Table 2. Summary characteristics of the main antibacterial protein families of crustaceans

\begin{tabular}{|c|c|c|c|c|c|}
\hline Family & General Structure & $\begin{array}{l}\text { Targets } \\
(\mathrm{MIC} \mu \mathrm{M})\end{array}$ & Origin & Species & $\begin{array}{l}\text { Key recent } \\
\text { reference(s) }\end{array}$ \\
\hline \multirow{2}{*}{ Crustins } & \multirow{2}{*}{$\begin{array}{l}\text { Cationic, cysteine- } \\
\text { rich. } \\
1-2 \text { WAP domain at } \\
\text { C terminus }\end{array}$} & $G-(5-50)$ & $\begin{array}{l}\text { Carcinin purified from } \\
\text { haemocytes }\end{array}$ & \multirow{2}{*}{$\begin{array}{l}\text { All } \\
\text { crustaceans } \\
\text { studied to } \\
\text { date. }\end{array}$} & $\begin{array}{l}\text { Smith et al., } \\
2008\end{array}$ \\
\hline & & Yeast (12.5-50) & $\begin{array}{l}\text { Others from haemocyte } \\
\text { cDNA \&, ESTs }\end{array}$ & & $\begin{array}{l}\text { Sperstad et al., } \\
2009\end{array}$ \\
\hline \multirow{4}{*}{ Penaeidins } & \multirow{4}{*}{$\begin{array}{l}\text { Cationic } \\
\text { Proline and } \\
\text { cysteine-rich } \\
\text { domains }\end{array}$} & G- $(2.5->40)$ & \multirow{4}{*}{$\begin{array}{l}1 \text { isolated as native } \\
\text { protein from haemocytes. } \\
\text { Haemocyte cDNA library } \\
\text { \& ESTs }\end{array}$} & \multirow{4}{*}{$\begin{array}{l}\text { Penaeid } \\
\text { shrimp only }\end{array}$} & \multirow{4}{*}{$\begin{array}{l}\text { Song \& Li, } \\
2014\end{array}$} \\
\hline & & $\mathrm{G}+(0.6-5)$ & & & \\
\hline & & Fungi (5-10) & & & \\
\hline & & Yeast $(>100)$ & & & \\
\hline \multirow{4}{*}{$\begin{array}{l}\text { Anti- } \\
\text { lipopolysaccharide } \\
\text { factors (ALF) }\end{array}$} & 3 a-helices & G- $(0.0095-50)$ & Identified from EST & \multirow{4}{*}{$\begin{array}{l}\text { Crab, } \\
\text { crayfish, } \\
\text { shrimp }\end{array}$} & \multirow{4}{*}{$\begin{array}{l}\text { Rosa et al., } \\
2014 \\
\text { Tassanakajon } \\
\text { et al., } 2011\end{array}$} \\
\hline & \multirow[t]{3}{*}{$4 \beta$-sheets } & $\mathrm{G}+(0.19-50)$ & libraries & & \\
\hline & & Fungi (1.56-25) & $\begin{array}{l}\text { Localized in haemocytes } \\
\text { by immunocytochemistry }\end{array}$ & & \\
\hline & & $\begin{array}{l}\text { WSSV }\left(I C_{50}>2.5\right. \\
\mu \mathrm{M})\end{array}$ & $\begin{array}{l}\text { against recombinant } \\
\text { protein }\end{array}$ & & \\
\hline \multirow[b]{2}{*}{ Lysozyme } & Coiled, $3 \alpha$-helices & G- $(0.47)$ & Quantification of activity & \multirow{2}{*}{$\begin{array}{l}\text { Crab, } \\
\text { crayfish, } \\
\text { shrimp }\end{array}$} & \multirow{2}{*}{$\begin{array}{l}\text { Kaizu et al., } \\
2011\end{array}$} \\
\hline & $2 \beta$-sheets & $\mathrm{G}+(0.12)$ & Haemocyte cDNA library & & \\
\hline \multirow[b]{2}{*}{ Histones } & \multirow[t]{2}{*}{ Coiled, 3 a-helices } & G- $(1.5-5.0)$ & Purified from haemocytes & \multirow[t]{2}{*}{ Shrimp } & \multirow{2}{*}{$\begin{array}{l}\text { Arockiaraj et } \\
\text { al., } 2013 a\end{array}$} \\
\hline & & $\mathrm{G}+(0.5-1.0)$ & cDNA library & & \\
\hline
\end{tabular}


Table 3. Summary characteristics of individual antimicrobial peptides

\begin{tabular}{|c|c|c|c|c|c|}
\hline Peptide & Structure & $\begin{array}{c}\text { Targets } \\
\text { (MIC } \mu \mathrm{M}: \text { except where } \\
\text { specified) }\end{array}$ & Origin & Species & $\begin{array}{l}\text { Key recent } \\
\text { reference(s) }\end{array}$ \\
\hline $\begin{array}{l}\text { Bac-like } \\
(6.5 \mathrm{kDa})\end{array}$ & Proline-rich & $\begin{array}{l}\text { G- MIC not determined } \\
\text { G+ MIC not determined }\end{array}$ & $\begin{array}{l}\text { Purified from } \\
\text { haemolymph }\end{array}$ & $\begin{array}{l}\text { Crab, } \\
\text { Carcinus } \\
\text { maenas }\end{array}$ & $\begin{array}{l}\text { Relf et al., } \\
1999\end{array}$ \\
\hline $\begin{array}{l}\text { Arasin-1 } \\
(4.3 \mathrm{kDa})\end{array}$ & $\begin{array}{l}\text { Cationic, proline/ } \\
\text { arginine-rich. Four } \\
\text { cysteine residues }\end{array}$ & $\begin{array}{l}\text { G- }(0.8-12.5) \\
G+(0.8-12.5)\end{array}$ & $\begin{array}{l}\text { Purified from } \\
\text { haemolymph }\end{array}$ & $\begin{array}{l}\text { Crab, Hyas } \\
\text { araneus }\end{array}$ & $\begin{array}{l}\text { Stensvåg et } \\
\text { al., } 2008\end{array}$ \\
\hline $\begin{array}{l}\text { Hyastatin } \\
(11.7 \mathrm{kDa})\end{array}$ & $\begin{array}{l}\text { Cationic, glycine- } \\
\text { rich, pro-arg rich } \\
\text { regions. Six } \\
\text { cysteine residues }\end{array}$ & $\begin{array}{l}\text { G- }(12.5->50) \\
G+(0.4->50) \\
\text { Yeast }(6.3-12.5)\end{array}$ & $\begin{array}{l}\text { Purified from } \\
\text { haemolymph }\end{array}$ & $\begin{array}{l}\text { Crab, Hyas } \\
\text { araneus }\end{array}$ & $\begin{array}{l}\text { Sperstad et al., } \\
2009\end{array}$ \\
\hline $\begin{array}{l}\text { Callinectin } \\
(3.7 \mathrm{kDa})\end{array}$ & $\begin{array}{l}\text { Cationic. Proline/ } \\
\text { Arginine-rich }\end{array}$ & G- (LC 1.44) & $\begin{array}{l}\text { Purified from } \\
\text { haemolymph }\end{array}$ & $\begin{array}{l}\text { Crab, } \\
\text { Callinectes } \\
\text { sapidus }\end{array}$ & $\begin{array}{l}\text { Noga et al., } \\
2011\end{array}$ \\
\hline $\begin{array}{l}\text { Defensin-like } \\
(6.7-7.1 \mathrm{kDa})\end{array}$ & $\begin{array}{l}\alpha \text {-helix, } 3 \beta \text {-sheets, } \\
\text { high level of } \\
\text { homogeny to } \beta \text { - } \\
\text { defensins }\end{array}$ & Not determined & Haemocyte cDNA library & $\begin{array}{l}\text { Spiny lobster, } \\
\text { Panulirus } \\
\text { japonicus, } \\
\text { Panulirus } \\
\text { argus }\end{array}$ & $\begin{array}{l}\text { Pisuttharachai } \\
\text { et al., } 2009 \\
\text { Montero-Alejo } \\
\text { et al., } 2012\end{array}$ \\
\hline $\begin{array}{l}\text { Scygonadin } \\
(10.8 \mathrm{kDa})\end{array}$ & $\begin{array}{l}\text { Anionic, } 2 \text { cysteine } \\
\text { residues }\end{array}$ & $\mathrm{G}+(\mathrm{IC} 90125 \mu \mathrm{g} / \mathrm{ml})$ & $\begin{array}{l}\text { Purified from seminal } \\
\text { plasma }\end{array}$ & $\begin{array}{l}\text { Crab, Scylla } \\
\text { paramamosain }\end{array}$ & $\begin{array}{l}\text { Huang et al., } \\
2006 \\
\text { Xu et al., } 2011\end{array}$ \\
\hline $\begin{array}{l}\text { SSAP (Scylla serrata } \\
\text { antimicrobial peptide) } \\
(11.4 \mathrm{kDa})\end{array}$ & $\begin{array}{l}\text { Similar to } \\
\text { scygonadin }\end{array}$ & $\begin{array}{l}\text { G- }\left(12.5-50 \mu \mathrm{g} \mathrm{ml}^{-1}\right) \\
\mathrm{G}+\left(25-100 \mu \mathrm{gll}^{-1}\right)\end{array}$ & $\begin{array}{l}\text { Purified from } \\
\text { haemolymph }\end{array}$ & $\begin{array}{l}\text { Crab, Scylla } \\
\text { paramamosain }\end{array}$ & $\begin{array}{l}\text { Yedery \& } \\
\text { Reddy., } 2009\end{array}$ \\
\hline $\begin{array}{l}\text { Stylicin } \\
(8.9 \mathrm{kDa})\end{array}$ & $\begin{array}{l}\text { Anionic, } \\
\text { cysteine/proline- } \\
\text { rich }\end{array}$ & $\begin{array}{l}\text { G- }(40-80) \\
\text { Fungi }(2.5)\end{array}$ & EST sequence & $\begin{array}{l}\text { Shrimp, } \\
\text { Litopenaeus } \\
\text { stylirosis }\end{array}$ & $\begin{array}{l}\text { Rolland et al., } \\
2010\end{array}$ \\
\hline
\end{tabular}




\begin{tabular}{|c|c|c|c|c|c|}
\hline $\begin{array}{l}\text { Armadillidin } \\
(5.2 \mathrm{kDa})\end{array}$ & $\begin{array}{l}\text { Cationic, glycine } \\
\text { rich }\end{array}$ & $G+(0.5-1.25)$ & $\begin{array}{l}\text { Purified from } \\
\text { haemolymph }\end{array}$ & $\begin{array}{l}\text { Isopod, } \\
\text { Armadillidium } \\
\text { vulgare }\end{array}$ & $\begin{array}{l}\text { Herbiniere et } \\
\text { al., } 2005\end{array}$ \\
\hline $\begin{array}{l}\text { CMCC-1 } \\
(0.2-0.71 \mathrm{kDa})\end{array}$ & Not determined & $\mathrm{G}+\left(5 \mathrm{mg} \mathrm{ml}^{-1}\right)$ & $\begin{array}{l}\text { Purified from whole body } \\
\text { homogenate }\end{array}$ & $\begin{array}{l}\text { Krill, } \\
\text { Euphausia } \\
\text { superba }\end{array}$ & $\begin{array}{l}\text { Zhao et al., } \\
2013\end{array}$ \\
\hline $\begin{array}{l}\text { Astacidin } \\
(1.9 \mathrm{kDa})\end{array}$ & $\begin{array}{l}\beta \text {-sheet peptide } \\
\text { cleaved from } \\
\text { haemocyanin }\end{array}$ & $\begin{array}{l}G-(15->20) \\
G+(1.9->20)\end{array}$ & $\begin{array}{l}\text { Purified from } \\
\text { haemolymph }\end{array}$ & $\begin{array}{l}\text { Crayfish, } \\
\text { Pacifasticus } \\
\text { leniusculus, } \\
\text { Procambarus } \\
\text { clarkii }\end{array}$ & Shi et al., 2014 \\
\hline
\end{tabular}


Table 4. Representative examples of crustin gene expression with immune challenges

\begin{tabular}{|c|c|c|c|c|}
\hline \multicolumn{2}{|c|}{ Experimental conditions } & \multicolumn{2}{|l|}{ Species } & $\begin{array}{l}\text { Key recent } \\
\text { reference(s) }\end{array}$ \\
\hline Bacteria & $\begin{array}{c}\text { G-* } \\
\text { G- } \\
\text { G+ } \\
\text { G+ } \\
\text { G -, G+ } \\
\text { G-, G+ } \\
\text { G-, G+ } \\
\text { G-, G+ } \\
\text { G-, G+ } \\
\text { G-, G+ } \\
\text { G-, G+ } \\
\text { G- }\end{array}$ & $\begin{array}{ll}\downarrow & \text { E. sinensis } \\
\uparrow & \text { E. sinensis } \\
\downarrow & \text { E. sinensis } \\
\uparrow & \text { F. indicus } \\
\mathrm{NC} & \text { H. arenaeus } \\
\uparrow & \text { M. rosenbergii } \\
\uparrow & \text { M. japonicus } \\
\mathrm{NC} & \text { M. japonicus } \\
\uparrow & \text { M. japonicus } \\
\mathrm{NC} & \text { P. monodon } \\
\uparrow & \text { P. trituberculatus } \\
\uparrow & \text { S.paramamosain }\end{array}$ & $\begin{array}{l}\mathrm{HC} \\
\mathrm{HC} \\
\mathrm{HC}, \mathrm{GL} \\
\text { Post-larvae } \\
\mathrm{HC} \\
\mathrm{HC} \\
\mathrm{HC} \\
\mathrm{EP} \\
\mathrm{GL} \\
\mathrm{GU} \\
\mathrm{HC} \\
\mathrm{HC}\end{array}$ & $\begin{array}{l}\text { Meng et al., } 2014 \\
\text { Li et al., } 2012 \\
\text { Mu et al., } 2011 \\
\text { Nayak et al., } 2011 \\
\text { Sperstad et al., } 2010 \\
\text { Arockiaraj et al., } 2013 \mathrm{~b} \\
\text { Liu et al., } 2015 \\
\text { Kim et al., } 2012 \\
\text { Kim et al., } 2012 \\
\text { Soonthornchei et al., } 2010 \\
\text { Cui et al., } 2012 \\
\text { Zhang et al., } 2015 a\end{array}$ \\
\hline Virus & WSSV & $\begin{array}{l}\uparrow \text { L. vannamei } \\
\uparrow \downarrow \text { M. japonicus } \\
\uparrow \text { M. rosenbergii } \\
\uparrow \text { M. rosenbergii } \\
\uparrow \downarrow \text { P. monodon } \\
\text { NC P. monodon } \\
\uparrow \downarrow P . \text { trituberculatus } \\
\uparrow \text { P. clarkii }\end{array}$ & $\begin{array}{l}\text { GL, HC, HP } \\
\mathrm{HC} \\
\mathrm{HC} \\
\mathrm{HP} \\
\mathrm{HC} \\
\mathrm{HC} \\
\mathrm{HC} \\
\mathrm{HC}\end{array}$ & $\begin{array}{l}\text { Taju et al., } 2015 \\
\text { Hipolito et al., } 2013 \\
\text { Arockiaraj et al., } 2013 \\
\text { Ren et al., } 2012 \\
\text { Donpudsa et al., } 2014 \\
\text { Jeswin et al., } 2012 \\
\text { Liu et al., } 2012 \\
\text { Shi et al., } 2010\end{array}$ \\
\hline Fungi & $\begin{array}{l}\text { Yeast } \\
\text { Fungi }\end{array}$ & $\begin{array}{l}\uparrow \text { E. sinensis } \\
\uparrow \text { P. trituberculatus }\end{array}$ & $\begin{array}{l}\mathrm{HC} \\
\mathrm{HC}\end{array}$ & $\begin{array}{l}\text { Li et al., } 2012 \\
\text { Cui et al., } 2012\end{array}$ \\
\hline Imı & nulation & $\begin{array}{l}\uparrow \text { L. vannamei } \\
\downarrow \text { L. vannamei } \\
\uparrow \text { M. japonicus } \\
\downarrow \text { M. japonicus } \\
\uparrow \quad \text { M. japonicus } \\
\uparrow \quad \text { P. monodon } \\
\uparrow \quad \text { P. monodon } \\
\uparrow \downarrow \text { P. monodon } \\
\uparrow \text { P. monodon }\end{array}$ & $\begin{array}{l}\text { GU } \\
\text { HP } \\
\text { GU } \\
\text { HP } \\
\text { HMPT } \\
\text { GL } \\
\text { HC } \\
\text { HC } \\
\text { Post-larvae }\end{array}$ & $\begin{array}{l}\text { Rungrassamee et al., } 2014 \\
\text { Rungrassamee et al., } 2014 \\
\text { Maeda et al., } 2013 \\
\text { Maeda et al., } 2013 \\
\text { Biswas et al., } 2012 \\
\text { Sudheer et al., } 2015 \\
\text { Babu et al., } 2013 \\
\text { Antony et al., } 2011 \\
\text { Wilson et al., } 2015\end{array}$ \\
\hline
\end{tabular}

Data from 2010 onwards. Abbreviations: G-/G+: Gram negative/Gram positive; WSSV: White spot syndrome virus; BR: brain; EP: epidermis; GL: gill; GU: gut; HC: haemocyte; HP: hepatopancreas; HT: heart; HMPT: haematopoietic tissue; MU: muscle

* Spiroplasma eriocheris: mollicute (wall-less) bacterial crustacean pathogen 
Table 5: Representative examples of penaeidin gene expression with immune challenges

\begin{tabular}{|c|c|c|c|c|}
\hline \multicolumn{2}{|c|}{ Experimental conditions } & Species & $\begin{array}{r}\text { Penaeidi } \\
\text { Tissue }\end{array}$ & $\begin{array}{l}\text { S } \\
\text { Key recent } \\
\text { eference(s) }\end{array}$ \\
\hline Bacteria & $\begin{array}{c}\text { G- } \\
\text { G- } \\
\text { G- } \\
\text { G-, G+ }\end{array}$ & $\begin{array}{ll}\uparrow & F . \text { indicus } \\
\uparrow & F . \text { indicus } \\
\uparrow & P . \text { monodon } \\
\text { NS } & P . \text { monodon }\end{array}$ & $\begin{array}{l}\text { HC } \\
\text { Post-larvae } \\
\text { Post-larvae } \\
\text { GU }\end{array}$ & $\begin{array}{l}\text { Shanthi \& Vaseeharan, } 2012 \\
\text { Nayak et al., } 2011 \\
\text { Nayak et al., } 2010 \\
\text { Soonthornchai al., } 2010\end{array}$ \\
\hline Virus & WSSV & $\begin{array}{ll}\uparrow & \text { P. monodon } \\
\uparrow \downarrow & P . \text { monodon } \\
\uparrow & \text { P. monodon }\end{array}$ & $\begin{array}{l}\mathrm{HC} \\
\mathrm{HC} \\
\mathrm{HC}\end{array}$ & $\begin{array}{l}\text { Antony et al., } 2011 \\
\text { Jeswin et al., } 2013 \\
\text { Woramongcolchai et al., } \\
2011\end{array}$ \\
\hline Immunost & & $\begin{array}{l}\uparrow \text { L. vannamei } \\
\uparrow \text { L. vannamei } \\
\text { NC L. vannamei } \\
\uparrow \text { M. japonicus } \\
\uparrow \text { M. japonicus } \\
\uparrow \text { P. monodon } \\
\uparrow \text { P. monodon } \\
\text { 个 NC P. monodon } \\
\text { NC P. monodon }\end{array}$ & $\begin{array}{l}\text { HC } \\
\text { HP, GU } \\
\text { MU } \\
\text { HMPT } \\
\text { HT, IN, HMPT } \\
\text { HC } \\
\text { HC } \\
\text { Post-larvae } \\
\text { GL }\end{array}$ & $\begin{array}{l}\text { Hao et al., } 2014 \\
\text { Rungrassamee et al., } 2013 \\
\text { Zhao et al., } 2012 \\
\text { Biswas et al., } 2012 \\
\text { Kono et al., } 2014 \\
\text { Antony et al., } 2011 \\
\text { Babu et al., } 2013 \\
\text { Wilson et al., } 2015 \\
\text { Sudheer et al., } 2015\end{array}$ \\
\hline
\end{tabular}

Data from 2010 onwards. Abbreviations: G-/G+: Gram negative/Gram positive; WSSV: White spot syndrome virus; BR: brain; EP: epidermis; GL: gill; GU: gut; HC: haemocyte; HP: hepatopancreas; HT: heart; HMPT: haematopoietic tissue; MU: muscle 
Table 6. Representative examples of ALF gene expression with immune challenges

\begin{tabular}{|c|c|c|c|c|}
\hline \multicolumn{2}{|c|}{ Experimental conditions } & \multicolumn{3}{|c|}{ ALF } \\
\hline Bacteria & $\begin{array}{c}\text { G - } \\
\text { G-, G+ } \\
\text { G-, G+ } \\
\text { G- } \\
\text { G- } \\
\text { G-, G+ } \\
\text { G- }\end{array}$ & $\begin{array}{ll}\uparrow & \text { E. sinensis } \\
\uparrow & \text { F. chinensis } \\
\downarrow & \text { M. rosenbergii } \\
\uparrow & \text { M. japonicus } \\
\downarrow \uparrow & \text { P. trituberculatus } \\
\uparrow & \text { P. clarkii } \\
\uparrow & \text { S. paramamosain }\end{array}$ & $\begin{array}{l}\mathrm{HC} \\
\mathrm{CT} \\
\mathrm{HP} \\
\mathrm{HMPT} \\
\mathrm{HC} \\
\mathrm{HC} \\
\mathrm{HC}\end{array}$ & $\begin{array}{l}\text { Zhang et al., } 2010 b \\
\text { Li et al., } 2014 \\
\text { Ren et al., } 2012 \\
\text { Mekata et al., } 2010 \\
\text { Liu et al., 2010; } 2013 \\
\text { Sun et al., } 2011 \\
\text { Sun et al., } 2015\end{array}$ \\
\hline Virus & WSSV & $\begin{array}{l}\uparrow \text { L. vannamei } \\
\uparrow \text { M. rosenbergii } \\
\uparrow \text { P. monodon } \\
\text { † P. clarkii } \\
\uparrow \text { S. serrata }\end{array}$ & $\begin{array}{l}\text { Various tissues } \\
\text { HP } \\
\text { HC } \\
\text { HC } \\
\text { HC }\end{array}$ & $\begin{array}{l}\text { Liu et al., } 2014 \\
\text { Ren et al., } 2012 \\
\text { Antony et al., } 2011 \\
\text { Sun et al., } 2011 \\
\text { Sun et al., } 2015\end{array}$ \\
\hline & & $\begin{array}{l}\uparrow \text { E. sinensis } \\
\uparrow \quad \text { L. vannamei }\end{array}$ & $\begin{array}{l}\mathrm{HC} \\
\mathrm{HC}\end{array}$ & $\begin{array}{l}\text { Zhang et al., } 2010 \mathrm{~b} \\
\text { Rosa et al., } 2013\end{array}$ \\
\hline Imm & nulation & $\begin{array}{l}\uparrow \text { M. japonicus } \\
\uparrow \text { P. monodon }\end{array}$ & $\begin{array}{l}\mathrm{HP} \\
\mathrm{HC}\end{array}$ & $\begin{array}{l}\text { Maeda et al., } 2013 \\
\text { Babu et al., } 2013\end{array}$ \\
\hline
\end{tabular}

Data from 2010 onwards. Abbreviations: G-/G+: Gram negative/Gram positive; WSSV: White spot syndrome virus; BR: brain; EP: epidermis; GL: gill; GU: gut; HC: haemocyte; HP: hepatopancreas; HT: heart; HMPT: haematopoietic tissue; MU: muscle 